\title{
Mineralogical and Chemical Tracing of Dust Variation in an Underground Historic Salt Mine
}

\author{
Aleksandra Puławska ${ }^{1,2, *(\mathbb{D})}$, Maciej Manecki ${ }^{1}$ (D) and Michał Flasza $^{2,3}$ (D) \\ 1 Department of Mineralogy, Petrography and Geochemistry, Faculty of Geology, Geophysics and \\ Environmental Protection, AGH University of Science and Technology, 30-059 Kraków, Poland; \\ gpmmanec@cyf-kr.edu.pl \\ 2 Bochnia Salt Mine, 32-700 Bochnia, Poland; mflasza@gmail.com \\ 3 KGHM CUPRUM Ltd., R\&D Centre, 53-659 Wrocław, Poland \\ * Correspondence: alexpulawska@gmail.com
}

Citation: Puławska, A.; Manecki, M.; Flasza, M. Mineralogical and Chemical Tracing of Dust Variation in an Underground Historic Salt Mine. Minerals 2021, 11, 686. https:/ doi.org/10.3390/min11070686

Academic Editor: Melina Macouin

Received: 12 May 2021

Accepted: 24 June 2021

Published: 26 June 2021

Publisher's Note: MDPI stays neutral with regard to jurisdictional claims in published maps and institutional affiliations.

Copyright: (c) 2021 by the authors. Licensee MDPI, Basel, Switzerland. This article is an open access article distributed under the terms and conditions of the Creative Commons Attribution (CC BY) license (https:/ / creativecommons.org/licenses/by/ $4.0 /)$.

\begin{abstract}
The aim of this study was to investigate the causes of the evolution of atmospheric dust composition in an open-to-public subterranean site (UNESCO-recognized historic mine) at increasing distances from the air intake. The role of the components imported with atmospheric air from the surface was compared with natural and anthropogenic sources of dust from inside the mine. Samples of deposited dust were directly collected from flat surfaces at 11 carefully selected sites. The morphological, mineralogical, and chemical characteristics were obtained using scanning electron microscopy (SEM), X-ray diffraction (XRD), and inductively coupled plasma spectroscopy (ICP). The study showed that the air in the underground salt mine was free of pollutants present in the ambient air on the surface. Most of the components sucked into the mine by the ventilation system from the surface (regular dust, particulate matter, gaseous pollutants, biogenic particles, etc.) underwent quick and instantaneous sedimentation in the close vicinity of the air inlet to the mine. The dust settled in the mine interior primarily consisted of natural geogenic particles, locally derived from the weathering of the host rock (halite, anhydrite, and aluminosilicates). This was confirmed by low values of enrichment factors (EF) calculated for minor and trace elements. Only one site, due to the tourist railroad and the associated local intensive tourist traffic, represented the anthropogenic sources of elevated concentrations of ferruginous particles and accompanied metals ( $\mathrm{P}, \mathrm{Cr}, \mathrm{Mn}$, $\mathrm{Co}, \mathrm{Ni}, \mathrm{Cu}, \mathrm{As}, \mathrm{Mo}, \mathrm{Cd}, \mathrm{Sn}, \mathrm{Sb}, \mathrm{Pb}$, and $\mathrm{W})$. The gravitational deposition of pollutants from these sources limits the effects of the emissions to the local range. The used methodology and the results are universal and might also apply to other mines, caves, or underground installations used for museums, tourists, or speleotherapeutic purposes.
\end{abstract}

Keywords: underground dust; air pollution; tourist mine; anthropogenic impact; railway; trace elements; EF; subterranean; speleotherapy

\section{Introduction}

Atmospheric particulate matter (PM) may be emitted into the atmosphere by natural geochemical processes, as well as a wide range of human activities. As PM is removed from the atmosphere by depositional processes, surface dust is considered an important environmental indicator of atmospheric contamination [1,2]. Thus, many studies devoted to chemical characterization and source identification of deposited dust have been carried out in outdoor and indoor public utility environments, including those on some heritage objects [3-6]. However, there has been limited research of this kind performed in open-topublic subterranean sites.

The underground spaces formed by the exploitation of minerals (mines) or by the karst processes (caves) have been increasingly viewed in terms of their heritage and recreational advantages $[7,8]$. These subterranean openings, naturally or manmade, are often characterized by remarkable cultural, ecological, mineralogical, environmental, industrial, and 
archeological values [9-13]. This is reflected in the UNESCO World Heritage list, which, presently includes 63 subterranean properties located in different parts of the globe [14]. In recent years, a notable growth of interest has been observed worldwide in re-profiling mining sites for tourist purposes due to the need for protection of their heritage, and the opportunity for the socioeconomic development of former industrial regions [15-19]. In addition to typical tourist activities, underground facilities in Europe often offer spa treatments (speleotherapy) that use particularly beneficial microclimates for people affected by respiratory problems [20-22]. Examples of such multidimensional post-mining activities include Bochnia and Wieliczka salt mines (Poland), which boast more than 750 years of history; have been labeled in the UNESCO World Heritage list; and are currently used for tourists, museums, recreation, and health care purposes.

Much has been written on the negative impact of mass tourism in subterranean environments, such as the input of $\mathrm{CO}_{2}[23,24]$, microbiological changes [25-28], and increase in PM concentrations [29,30]. Still, there are little data on the mineralogy and chemistry of PM collected directly from within such sites. While the mineralogical and chemical composition of PM in underground environments is believed to be simple, and dependent mostly on the parent rock, recent studies have found that, in open-access objects, there are much more complex compositions [22,31,32]. Puławska et al. [22] demonstrated that, similar to caves, the space of an underground salt mine could also suffer from degradation from external pollutants and from visitor disturbances. Mineralogical and chemical characterization of deposited dust have already proven beneficial in tracing sources of underground PM in mines and caves [33-35]. Nevertheless, more attention has been paid to environmental protection in caves than in underground mines [36-39]. Identification of air pollutants is particularly important in cultural and natural heritage mines, as well as in those where natural resources are traditionally used for medical purposes. Such information also appears important in light of the growing interest in the utilization of underground mined space for deep-underground laboratories and even new urban centers $[40,41]$.

For many formal, technical, and safety reasons, long-term continuous air monitoring is not conducted in most underground mines or caves used for touristic purposes. Moreover, previous studies show that air pollution in such facilities is low and subject to seasonal fluctuations; see, for example [25,29,42]. Therefore, the study of particulate matter collected by air filtration apparatuses allow for capturing only the momentary state of the mine atmosphere. Moreover, the amount of material collected is small, preventing full and representative mineralogical characterization. In contrast, analysis of dust deposited on flat surfaces in different parts of an underground installation allows comparison of average, long-term trends in the diversity of the amount and composition of airborne dust, both originating from distant sources and generated locally. We believe that our sampling strategy and analytical methods are applicable, not only to the studied salt mines, but also to other underground systems.

The aim of this study was to investigate and explain the causes of the evolution of atmospheric dust composition in an underground mine, currently open to the general public as a museum and sanatorium facility. At increasing distances from the air intake to the mine, the role of the components imported with atmospheric air from the surface was compared with the natural and anthropogenic sources of dust inside the mine. This was achieved by detailed mineralogical and chemical characterization of the deposited dusts using various analytical methods (inductively coupled plasma spectroscopy, X-ray diffraction, and scanning electron microscopy). Because the general pattern of ventilation and use by the open public is similar, the results are universal, and apply to other mines, caves, or underground installations used for museums, tourists, or speleotherapeutic purposes. Since decommissioned open-access mines are not subjected to regular air monitoring, the results of this study can be helpful in managing and shaping a policy aimed at the protection and conservation of subterranean objects of its kind. 


\section{Materials and Methods}

\subsection{Study Site}

The Bochnia Salt Mine located near Kraków in southern Poland was chosen as a testing ground for this research because it is a representative model for historical underground facilities, used nowadays for tourists, museums, recreational, and therapeutic purposes. The beginning of underground rock salt mining in Poland dates to the first half of the 13th century, when the salt mines in Bochnia and nearby Wieliczka were opened. However, this was preceded by the production of evaporated salt from brines, dating to the Neolithic times, ca 3500 BC [43]. These two mines constituted one of the earliest and most important European industrial operations of the time and today are jointly enlisted in the UNESCO World Heritage list [13]. After the end of industrial activity in 1990, the Bochnia Salt Mine focused on tourism, recreation and health care, and museum exhibitions. The mine consists of several dozens of kilometers of historical galleries, with works of art, subterranean chapels, statues, and decorative elements sculpted in the salt by miners. By adapting post-mining chambers and corridors for tourist purposes, an impressive underground functional space was created, which includes catering facilities, spa chambers, sports fields and facilities, multi-purpose halls, attractions, such as an underground battery train, and many different tourist routes $[13,22]$. Such multiple infrastructures and activities requiring controlled forced air circulation make it a model facility for studying the sources and mechanisms of atmospheric dust transport.

\subsection{Geological Background}

Salt deposits in the Bochnia and Wieliczka area comprise salt-rich strata belonging to an evaporate succession that originated in the Carpathian Foredeep, a part of the epicontinental sea, which existed between the Early Oligocene and late Middle Miocene [44]. The evaporate series of the Bochnia deposit is by rock salt, comprising claystone, anhydrite, mudstone, and zuber interbeds. A detailed lithological profile of the salt-bearing succession in the vicinities of Bochnia is shown in Figure 1. The strata underlying (Skawina Bed) and overlying (Chodenice Bed) the salt-bearing succession are usually represented by marly claystones and marly clayey shales [45]. Studies have reported that the uplift of the Carpathians in the Late Miocene resulted in the folding, local tectonic thickening, and uplifting of the Badenian evaporites [46,47]. The local accumulation of salt, with outcrops reaching the surface, facilitated the early development of salt mining in this area [48]. The present-day salt deposit in Bochnia stretches east-west, ca. $4.5 \mathrm{~km}$ in length and 200-300 m in thickness. The current extensive spatial structure of the historic mine is presented in Figure 2. A significant part of the mine is open to public. Due to many years of mining activity, the layers of pure rock salt have been almost completely extracted. Various types of northern and middle salts interlayered with anhydritic or salty claystones are observed on most of the mine sidewalls and ceilings. The geological heritage exposed in mining excavations has been brought under legal protection, with the relevant locations labeled as so-called "documentary sites" [13]. Mining supports are used for safety reasons, only in excavations where gangue rocks (claystone, anhydrite) comprise a substantial area of the excavation site.

\subsection{Ventilation System}

The mine is ventilated by a system of three connected shafts: the 19th century Trinitatis (downcast), the 16th century Campi (exhaust), and the 13th century Sutoris (exhaust) (Figure 2). Main fans located on the surface force $25 \mathrm{~m}^{3} / \mathrm{s}$ of fresh air into the mine through a brick-lined downcast shaft. The efficiency of mining ventilation is constantly controlled by a remote measurement and alarm system supervised by mine personnel and confirmed by laboratory analyses, as required by law. The mean air velocity is $2.8 \mathrm{~m} / \mathrm{s}$ at the mine inlet and, subsequently, gradually decreases as the air is distributed through the extensive network of underground workings. The current ventilation system was established in 2004 and was aimed at gaining natural air conditioning through the use of most peripheral non- 
tourist corridors near the air inlet. The relatively long air travel distance of approximately $1300 \mathrm{~m}$ through a network of underground pits helps to naturally smooth out the extremes of temperature and humidity of the intake air prior to reaching the protected historic workings [13]. However, the relative humidity $(\mathrm{RH})$ values measured in the Bochnia Salt Mine could exceed $80 \%$, particularly in the summer when warm ambient air cools down as it enters the mine, which results in an increase in $\mathrm{RH}$, and subsequent condensation of water vapor [22].

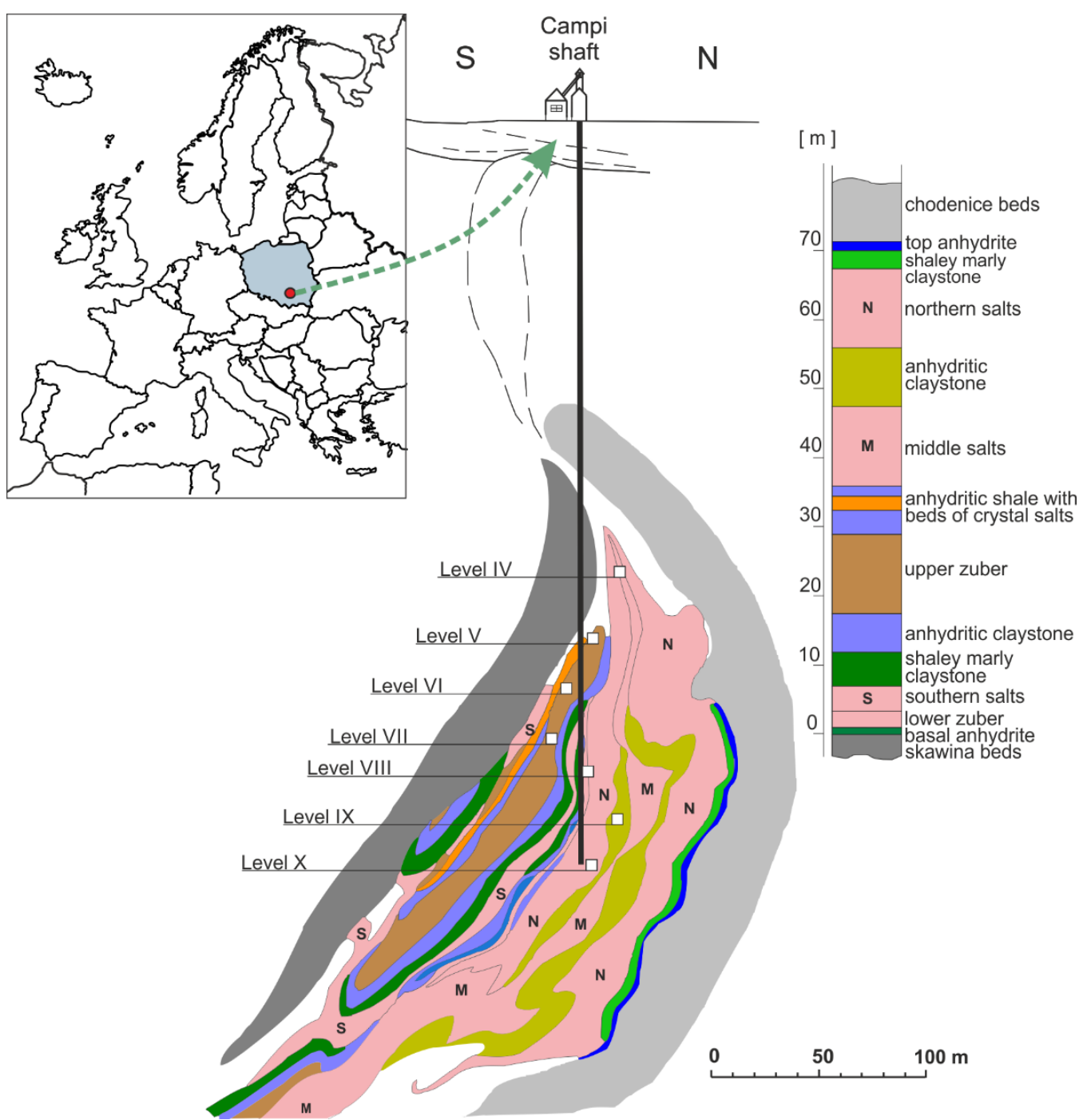

Figure 1. Geology of Bochnia salt deposit: a simplified structure of a cross-section around the Campi shaft and a lithostratigraphic profile of salt succession (according to Poborski [46], modified).

\subsection{Selection of the Sampling Sites}

To characterize the underground dust patterns and interpret the mineralogical and chemical composition and origin, the sampling points were arranged along the main air stream in the order of increasing distance from the air intake of the mine. After review of the literature [22], field observations, and analysis of the ventilation system, atmospherically deposited particles were collected at 11 different locations (Figure 2).

The first sampling site (E.1) is situated on the surface behind the fans forcing the air into the mine. The further four sampling sites are situated inside the mine, near the outlet of the downcast shaft, where a significant accumulation of atmospheric dust is observed (Figure 2). This atmospherically deposited dust covers the entire width of the 
floor (approximately $3 \mathrm{~m}$ ) and extends over a length of $250 \mathrm{~m}$. Deposited dusts reach on average the height of $10 \mathrm{~cm}$, with the maximum $(30 \mathrm{~cm})$ in the middle where the excavation curves and the minimum $(1 \mathrm{~cm})$ at the end of the accumulation. Based on the maintenance records, the time of accumulation of this dust was estimated to at least 10 years. Dust accumulation of this magnitude was only observed in this place in the mine. Therefore, the sampling sites were located at the beginning (E.2), middle (E.3), and at the end (E.4) of the deposition zone. The sample sites E.1, E.2, E.3, and E.4 were grouped in the entrance zone as they are situated nearby the Trinitatis shaft, and, thus, they are likely the most susceptible to outer particles introduced into the mine through the ventilation system. All these abovementioned sampling points are situated in excavations covered by old mining support. Point I.1 is situated $55 \mathrm{~m}$ behind the point E.4. The selection of further sampling sites was based on the sampling sites established and described in detail by Puławska et al. 2021 [22]. Briefly, points I.2, I.3, I.4, I.5, I.6, and I.7 are situated in the mine interior and arranged in the order of increasing distance from the air intake of the mine, where point I. 2 is situated in front of the tourist zone, and points I.3 to I.7 are located along the mine passages opened to the public. Site I.3 is situated on the route of railway that transports visitors from the Campi shaft to the beginning of selected trails. Based on the maintenance record, the time of dust accumulation in the mine interior exceeds one year. The locations of sampling sites are presented in Figure 2.

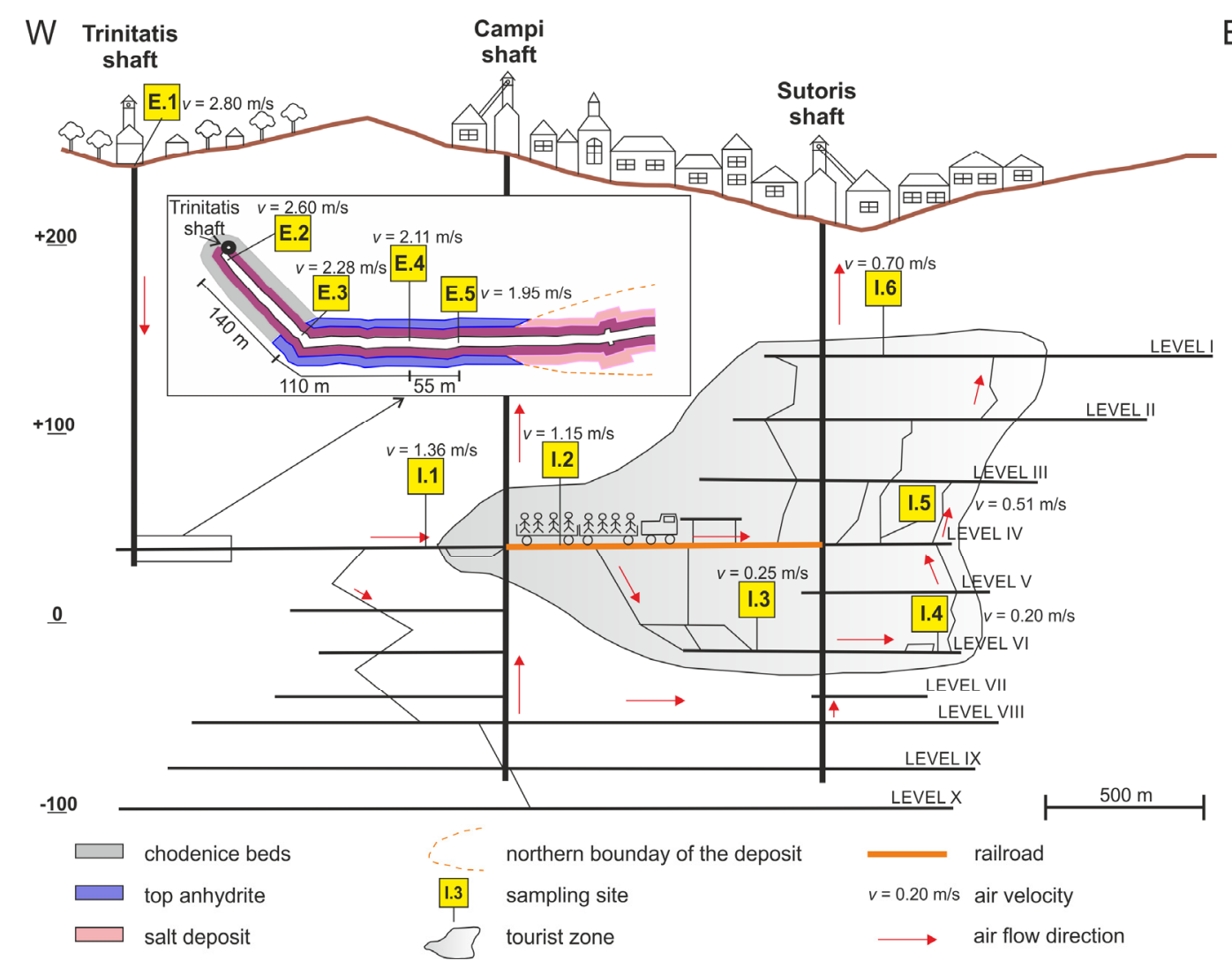

Figure 2. Location of the sampling sites in relation to airflow directions on a schematic longitudinal section of Bochnia Salt Mine.

\subsection{Sample Collection and Analytical Methods}

Complete qualitative and quantitative mineral composition analysis, microscopic characterization of particle morphology and composition, and elemental composition analysis (major, minor, and trace elements) were performed and compared for 11 deposited dust samples. Dry bulk samples 10-50 g in size were collected into sealed polyethylene containers using a brush. Samples from dust accumulation near the air inlet shaft (E.2, E.3, 
E.4) were collected directly from the floor of the dustpan, whereas samples E.1 and I.1-I.7, were collected from horizontally oriented non-metallic parts of the mining corridors.

Mineral components of PM were identified by powder X-ray diffractometry (XRD). The patterns were recorded with a Rigaku SmartLab diffractometer (Neu-Isenburg, Tokyo, Japan) in the range of $2-75^{\circ} 2 \theta$ with a step size of $0.05^{\circ}$ using graphite-monochromatized $\mathrm{Cu} \mathrm{K} \alpha$ radiation. The phases were identified using the ICCD database and XRAYAN software [49]. The detection limit varied for different minerals from 0.1 to $1 \mathrm{wt} . \%$. Quantitative analysis was carried out by Rietveld refinement using $\mathrm{ZnO}$ as standard. Amorphous substances were quantified but not identified.

Morphological and chemical microanalysis of particles was performed with a scanning electron microscopy (SEM, FEI Quanta model 200 FEG, FEI, Hillsboro, OR, USA) equipped with an energy dispersive spectroscopy (EDS) microanalyzer. A representative portion of each sample of dust was fixed on the sample holder with a carbon tape. The samples were coated with gold prior to imaging.

The elemental composition of dust ( $1 \mathrm{~g}$ sample) was determined by wet chemical analysis using acid digestion with $\mathrm{HNO}_{3}$ and $\mathrm{HCl}$ solutions at 3:1 in a microwave oven in $105^{\circ} \mathrm{C}$, for $2 \mathrm{~h}$, to obtain the pseudo total metal content. Analyses of $\mathrm{Al}, \mathrm{B}, \mathrm{Ba}, \mathrm{Ca}, \mathrm{Cr}, \mathrm{Cu}$, $\mathrm{Fe}, \mathrm{K}, \mathrm{Li}, \mathrm{Mg}, \mathrm{Mn}, \mathrm{Na}, \mathrm{Ni}, \mathrm{S}, \mathrm{Sr}, \mathrm{Zn}$, and $\mathrm{P}$ were performed by inductively coupled plasma optical emission spectrometry (ICP-OES, and Be, Ti, V, U, Co, As, Hg, Se, Sn, Zr, Mo, Ag, Cd, $\mathrm{Sb}, \mathrm{W}, \mathrm{Tl}$, and $\mathrm{Pb}$ were analyzed by inductively coupled plasma mass spectrometry (ICPMS. The samples were analyzed in the certified AGH-UST Hydrogeochemical Laboratory (certificate of accreditation AB 1050). The laboratory takes part in proficiency testing and inter laboratory comparisons obtaining satisfactory results (Z-score absolute value lower than 2). The precision of the analytical methods used, expressed as a relative standard deviation (\%RSD), was determined by the laboratory during a standard process of method validation and was lower than $20 \%$. The recovery values for all parameters were in the range of $94-105 \%$. Uncertainty values for all chemical compounds were in the range of $10-19 \%$. The limit of quantification (LOQ) values of the investigated major and minor elements were as follows: $0.1 \mathrm{mg} / \mathrm{kg}$ for Na, $0.05 \mathrm{mg} / \mathrm{kg}$ for Ca, $0.01 \mathrm{mg} / \mathrm{kg}$ for $\mathrm{Fe}, 0.01 \mathrm{mg} / \mathrm{kg}$ for $\mathrm{Al}, 1 \mathrm{mg} / \mathrm{kg}$ for $\mathrm{S}, 0.1 \mathrm{mg} / \mathrm{kg}$ for $\mathrm{Mg}, 0.2$ for K, $0.5 \mathrm{mg} / \mathrm{kg}$ for $\mathrm{P}, 0.005 \mathrm{mg} / \mathrm{kg}$ for Mn, $0.02 \mathrm{mg} / \mathrm{kg}$ for Sr, and $0.01 \mathrm{mg} / \mathrm{kg}$ for $\mathrm{Zn}$. The LOQ values for chemical analyses of trace elements are presented in Table 1. All results reported in this paper were blank corrected.

\subsection{Pollution Indices}

The enrichment factors (EFs) for metal elements in dust samples were used to distinguish their natural origin from anthropogenic sources and to evaluate the degree of anthropogenic influence. EFs for metals in dust were calculated as follows [50]:

$$
\mathrm{EF}=\frac{\mathrm{C}_{\mathrm{x}} / \mathrm{C}_{\text {ref (sample) }}}{\mathrm{C}_{\mathrm{x}} / \mathrm{C}_{\text {ref (background) }}}
$$

where $C_{x}$ represents the concentration of element $x$ and $C_{\text {ref }}$ is the concentration of a reference element. Similar to published assessments of dust and sediment contamination, $\mathrm{Al}$ was used as a reference element as it is assumed not to be enriched by local contamination [51-53]. Two calculation series were performed using different background values: the marine sediments concentrations from Turekian and Wedepohl [54] and local geochemical background concentrations, as suggested by Kowalska et al. [55] (from sample site I.7). Sampling point I.7 was chosen because it is farthest from the air intake and has some of the lowest EFs relative to marine sediments. According to Sutherland [56], five categories of pollution were distinguished: minimal $(\mathrm{EF}<2)$, moderate $(2-5)$, significant $(5-20)$, very high (20-40), and extreme (>40). EF values were also interpreted as suggested by Zhang and Liu [57]: EF values below 1.5 indicate that the presence of the element was entirely from materials from the Earth's crust or natural processes, whereas EF values above 1.5 suggest the contribution of anthropogenic sources. 
Table 1. Concentrations of $\mathrm{Al}$ and trace elements in dusts sampled at the consecutive sites.

\begin{tabular}{|c|c|c|c|c|c|c|c|c|c|c|c|c|}
\hline Element & LOQ & E.1 & E. 2 & E.3 & E.4 & I.1 & I. 2 & I. 3 & I.4 & I.5 & I.6 & I.7 \\
\hline $\mathrm{Al}$ & 0.00001 & 19.3 & 18.5 & 27.5 & 14.8 & $\begin{array}{c}\mathrm{g} / \mathrm{kg} \\
34.1 \\
\mathrm{mg} / \mathrm{kg}\end{array}$ & 32.1 & 18.5 & 15.9 & 35.4 & 21.6 & 31.0 \\
\hline $\mathrm{Ti}$ & 0.02 & 162.3 & 28.5 & 16.1 & 6.9 & 24.4 & 80.3 & 57.7 & 22.2 & 50.9 & 25.2 & 37.9 \\
\hline As & 0.001 & 7.1 & 6.7 & 10.0 & 5.2 & 11.0 & 4.5 & 9.9 & 4.2 & 2.4 & 5.4 & 4.0 \\
\hline B & 0.01 & 5.3 & 1.6 & 1.5 & bdl & 1.2 & 2.8 & 1.1 & bdl & 4.2 & 8.5 & 6.5 \\
\hline $\mathrm{Ba}$ & 0.01 & 60.0 & 45.5 & 74.1 & 31.4 & 185.0 & 64.6 & 74.6 & 45.6 & 56.5 & 48.1 & 95.9 \\
\hline $\mathrm{Cd}$ & 0.0003 & 2.1 & 1.9 & 3.2 & 1.6 & bdl & 2.9 & 12.5 & 2.6 & 2.2 & 2.3 & 2.2 \\
\hline Co & 0.0002 & 6.3 & 6.6 & 10.2 & 4.5 & 31.4 & 6.8 & 15.0 & 5.8 & 7.4 & 6.3 & 5.2 \\
\hline $\mathrm{Cr}$ & 0.01 & 21.0 & 20.1 & 20.1 & 14.3 & 40.1 & 39.1 & 109.8 & 22.5 & 34.0 & 29.6 & 22.2 \\
\hline $\mathrm{Cu}$ & 0.005 & 36.6 & 44.6 & 38.1 & 18.8 & 81.9 & 63.6 & 161.9 & 53.0 & 72.3 & 95.5 & 49.0 \\
\hline $\mathrm{Li}$ & 0.005 & 14.8 & 76.6 & 94.2 & 58.1 & 32.2 & 25.6 & 12.6 & 14.5 & 31.1 & 22.4 & 16.8 \\
\hline Mo & 0.0003 & 2.4 & 2.2 & 1.5 & 1.0 & 3.0 & 3.8 & 11.1 & 1.9 & 2.6 & 2.9 & 2.0 \\
\hline $\mathrm{Ni}$ & 0.05 & 11.4 & 26.3 & 37.9 & 18.23 & 39.7 & 29.8 & 65.9 & 21.3 & 26.6 & 30.2 & 23.2 \\
\hline $\mathrm{Pb}$ & 0.0001 & 14.8 & 23.4 & 14.6 & 7.2 & 32.9 & 12.4 & 14.6 & 7.4 & 13.6 & 12.7 & 9.8 \\
\hline $\mathrm{Rb}$ & 0.0003 & 87.1 & 34.4 & 58.2 & 26.1 & 51.4 & 42.5 & 61.8 & 47.9 & 37.6 & 37.3 & 32.1 \\
\hline $\mathrm{V}$ & 0.001 & 26.3 & 14.6 & 21.1 & 12.1 & 24.2 & 22.2 & 15.1 & 11.5 & 25.9 & 16.0 & 16.1 \\
\hline $\mathrm{Zr}$ & 0.002 & 7.3 & 5.6 & 6.5 & 2.7 & 7.7 & 9.7 & 6.2 & 3.9 & 5.7 & 4.3 & 4.8 \\
\hline & & & & & & $\mu \mathrm{g} / \mathrm{kg}$ & & & & & & \\
\hline $\mathrm{Ag}$ & 1.0 & 575.2 & 687.2 & 1387.4 & 994.5 & 910.8 & 1167.4 & 2813.1 & 833.3 & 2836.7 & 953.4 & 1281.4 \\
\hline $\mathrm{Be}$ & 0.5 & 400.3 & 372.4 & 649.7 & 269.7 & 604.3 & 597.7 & 325.3 & 285.3 & 577.4 & 334.8 & 382.1 \\
\hline Se & 10 & 455.0 & 1010.9 & 1721.3 & 0.0 & 1234.7 & 761.3 & 0.0 & 0.0 & 0.0 & 572.8 & 0.0 \\
\hline Sn & 1 & 548.4 & 1216.3 & 1913.8 & 430.2 & 279.3 & 950.0 & 8253.6 & 1788.6 & 1305.1 & 2200.0 & 1400.0 \\
\hline $\mathrm{Sb}$ & 0.2 & 277.3 & 410.5 & 30.1 & 2.5 & 55.3 & 1228.8 & 2202.8 & 419.4 & 399.3 & 1115.5 & 956.5 \\
\hline $\mathrm{Tl}$ & 20.0 & 314.0 & 167.1 & 227.1 & 178.6 & 439.8 & 187.9 & 120.6 & 125.8 & 201.2 & 138.1 & 196.9 \\
\hline $\mathrm{Hg}$ & 0.1 & 3.6 & 5.2 & 29.6 & 6.8 & 6.3 & 5.6 & 5.2 & 3.6 & 5.5 & 3.1 & 5.3 \\
\hline $\mathrm{U}$ & 0.1 & 2.6 & 599.8 & 1126.0 & 594.5 & 6.3 & 5.6 & 5.2 & 3.6 & 5.5 & 3.1 & 5.3 \\
\hline W & 0.3 & bdl & bdl & bdl & bdl & bdl & bdl & 551.6 & bdl & bdl & bdl & bdl \\
\hline
\end{tabular}

bdl—below detection limit.

\section{Results}

\subsection{Mineral Composition and Distribution}

Dust in the entrance zone differed in mineral content from dust in the mine interior (Figure 3). X-ray diffraction showed that halite, anhydrite, gypsum, and quartz represented the dominant mineral components in the mine interior (site I.1-I.7), accounting for up to $92 \mathrm{wt} . \%$ of the deposited material. In contrast, samples collected in the zone where outdoor air enters the mine (sites E.1-E.4) presented higher content of quartz, amorphous components, aluminosilicates, and markedly lower content of anhydrite. In addition, epsomite $\left(\mathrm{MgSO}_{4} \cdot 7 \mathrm{H}_{2} \mathrm{O}\right)$ was detected at sites E.3 and E.4, which is absent elsewhere. Beside this general contrast, several other relevant differences in the distribution of individual mineral components along the atmospheric airflow path could be observed.

Halite. The content of halite $(\mathrm{NaCl})$ increased along the atmospheric airflow into the mine through the air inlet shaft from $5 \mathrm{wt} . \%$ in the sample taken outdoors (E.1) to $32 \mathrm{wt} . \%$ at the end of underground dust accumulation near the outlet of this shaft (E.4). Subsequently, it significantly decreased to $1 \mathrm{wt} . \%$ at the next sampling site (I.1). At other locations in the mine interior, a consecutive increase in halite content was observed in relation to the values of site I.1, ranging between 4 wt.\% (I.2) and 41 wt.\% (I.4).

Sulfates. The content of gypsum $\left(\mathrm{CaSO}_{4} \cdot 2 \mathrm{H}_{2} \mathrm{O}\right)$, similarly to halite, increased along the atmospheric airflow in the mine through the air inlet shaft from $3 \mathrm{wt} . \%$ in the sample taken outdoors (E.1) to $12 \mathrm{wt} . \%$ at the end of entrance zone (E.4). The sample E.4 was additionally characterized by an unusually high presence $(9 \mathrm{wt} . \%)$ of epsomite $\left(\mathrm{MgSO}_{4} \cdot 7 \mathrm{H}_{2} \mathrm{O}\right)$. In contrast to dusts deposited near the air inlet shaft where almost no anhydrite $\left(\mathrm{CaSO}_{4}\right)$ was found, the samples collected from the mine interior (I.1-I.6) exhibited a very high content of this mineral (19-72 wt.\%), except for the furthest sampling site I.7, where gypsum (50 wt.\%) dominated over anhydrite. 


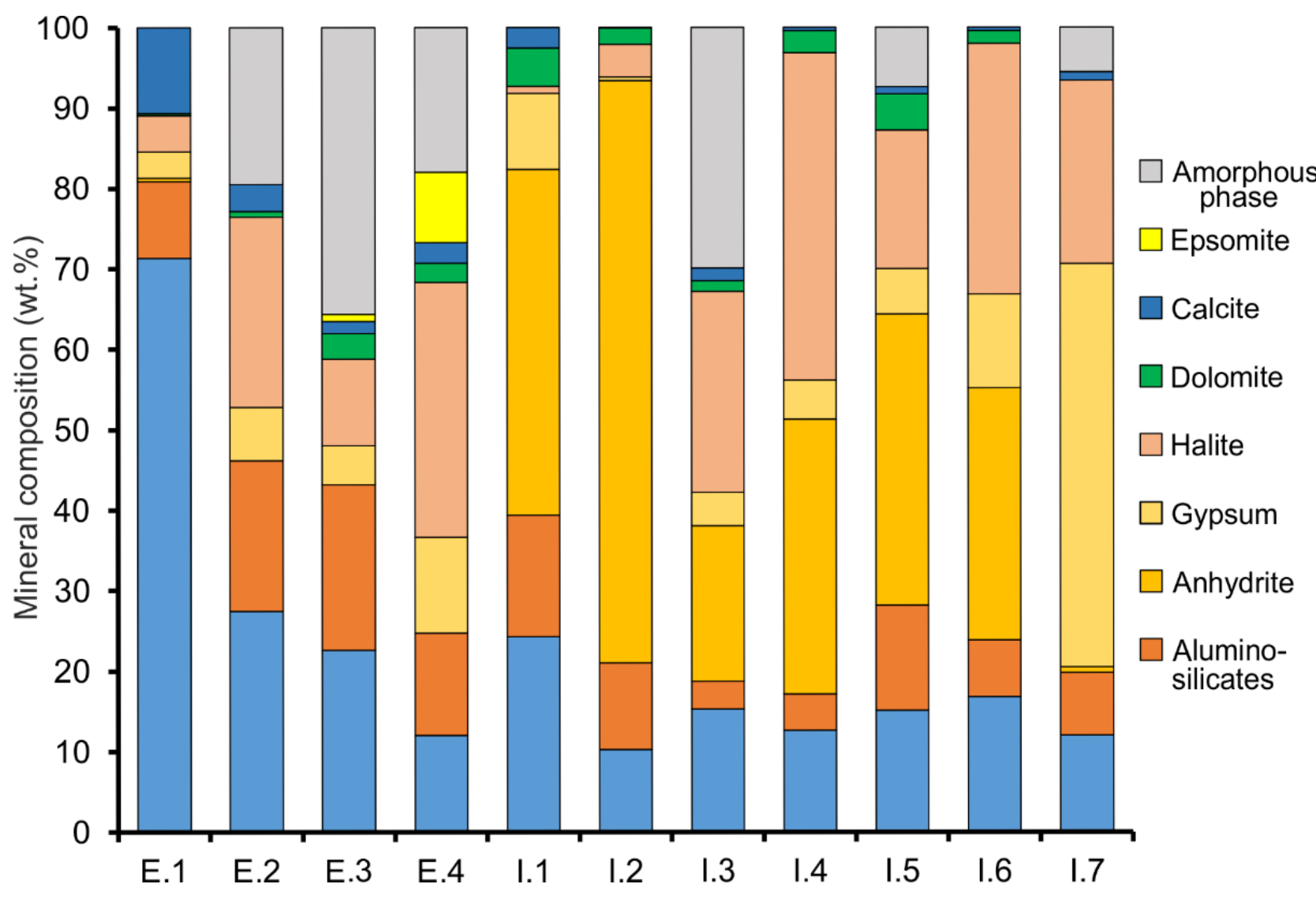

Figure 3. Mineral composition of dusts sampled at the consecutive sites (in wt.\%).

Quartz. The extremely high content of quartz $\left(\mathrm{SiO}_{2}\right)$ was observed in the sample E.1 taken outdoors (71 wt.\%), which gradually decreased to $12 \mathrm{wt} . \%$ at the end of underground dust accumulation (E.4). In the samples from the mine interior (I.1-I.7), the contents of quartz were relatively stable and varied in the range of from 10 to $24 \mathrm{wt} . \%$.

Aluminosilicates. This group of minerals, comprising feldspars, plagioclase and potassium feldspar, and muscovite, as well as clay minerals (illite, chlorite, and kaolinite) was more abundant in the dusts accumulated at the entrance zone (accounting in average for $15 \mathrm{wt.} \%$ ), whereas in the inner part of the mine, it accounted on average for $9 \mathrm{wt} . \%$. Only albite $\left(\mathrm{Na}\left[\mathrm{AlSi}_{3} \mathrm{O}_{8}\right]\right)$ and anorthite $\left(\mathrm{Ca}\left[\mathrm{Al}_{2} \mathrm{Si}_{2} \mathrm{O}_{8}\right]\right)$ represented this group in the sample from outdoors (E.1). Similar to quartz, their content decreased in subsequent dust samples collected in the entrance zone. In the underground dust accumulation (sites E.2-E.4), additionally muscovite $\left(\mathrm{KAl}_{2}\left(\mathrm{AlSi}_{3} \mathrm{O}_{10}\right)(\mathrm{F}, \mathrm{OH})_{2}\right)$, kaolinite $\left(\mathrm{Al}_{4}\left[\mathrm{Si}_{4} \mathrm{O}_{10}\right](\mathrm{OH})_{8}\right)$, and chlorite $\left((\mathrm{Fe}, \mathrm{Mg}, \mathrm{Al})_{6}\left[(\mathrm{OH})_{2}(\mathrm{Si}, \mathrm{Al})_{4} \mathrm{O}_{10}\right]\right)$ were found, while in the inner part of the mine, illite $\left(\left(\mathrm{K}, \mathrm{H}_{3} \mathrm{O}\right)(\mathrm{Al}, \mathrm{Mg}, \mathrm{Fe})_{2}(\mathrm{Si}, \mathrm{Al})_{4} \mathrm{O}_{10}\left[(\mathrm{OH})_{2},\left(\mathrm{H}_{2} \mathrm{O}\right)\right]\right)$ and muscovite dominated. Albite was present in various proportions in all sampling sites in the mine interior.

Calcite. The distribution of calcite $\left(\mathrm{CaCO}_{3}\right)$ showed a similar trend to the quartz distribution, with a maximum value observed in the sample collected outdoors (E.1, $11 \mathrm{wt.} \%$ ) and a decrease in content toward the mine interior. The content of calcite inside the mine (sites I.1-I.7) was very low and varied between 0.1 and $2.5 \mathrm{wt} . \%$.

Dolomite. The content of dolomite $\left(\mathrm{CaMg}\left[\mathrm{CO}_{3}\right]_{2}\right)$ varied across the sampling sites both in the mine entrance zone (0.2-5\%) and mine interior (0-5 wt. \%). Similarly to halite and gypsum, however, the higher content was observed after the air passed through the shaft, i.e., in an underground dust accumulation, than in the sample taken outdoors.

Amorphous phase. Amorphous substances were one of the most prominent components of dust deposited near the underground outlet of air intake shaft and ranged between 36 wt.\% (E.3) and 18 wt.\% (E.4). Toward the interior of the mine, the elevated concentrations 
of amorphous components were detected in site I.3 located on the underground railway route $(30 \mathrm{wt} . \%)$ and at a lower level at sites I.5 (7 wt.\%) and I.7 (6 wt.\%) located on tourist routes.

\subsection{Micromorphology of Particles}

SEM/EDS analysis revealed significant variation in size, morphology, abundance, and composition of particles deposited in the entrance zone and in the mine interior (Figure 4). The particles deposited in the mine entrance zone usually appeared as irregularly shaped large aggregates (Figure 4a). Most large- and medium-size aggregates are composed of variety of elements: $\mathrm{Na}, \mathrm{K}, \mathrm{Mg}, \mathrm{Fe}, \mathrm{Ti}, \mathrm{Cl}, \mathrm{Al}, \mathrm{Si}$, and $\mathrm{O}$. These aggregates frequently reach up to $200 \mu \mathrm{m}$ in size.

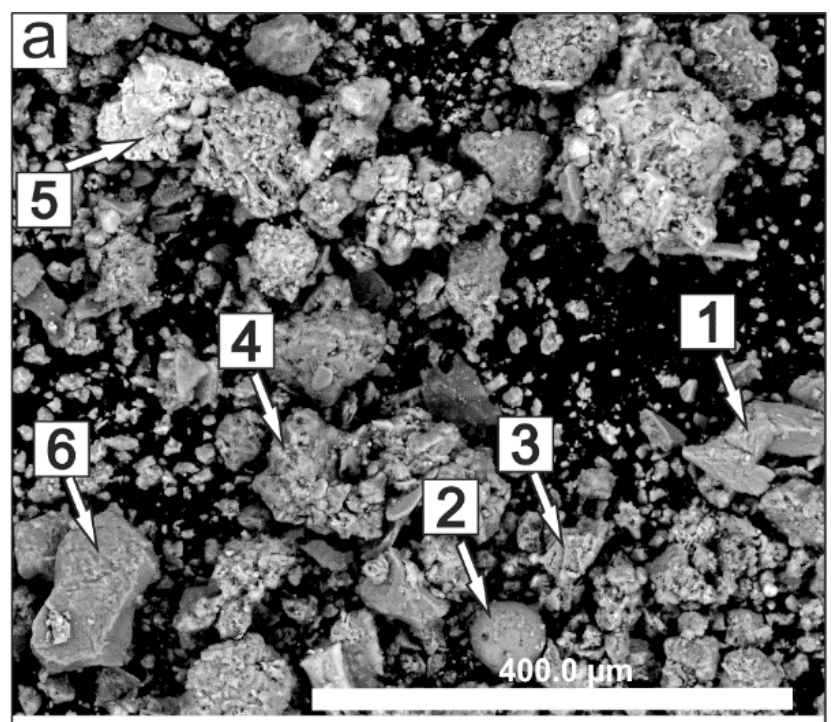

1. $\mathrm{Ca} / \mathrm{C} / \mathrm{O}$

2. $\mathrm{Ti} / \mathrm{Fe} / \mathrm{Al} / \mathrm{Si} / \mathrm{O}$

3. $\mathrm{Ca} / \mathrm{Mg} / \mathrm{Cl} / \mathrm{C} / \mathrm{Al} / \mathrm{Si} / \mathrm{O}$

4. $\mathrm{Mg} / \mathrm{Ca} / \mathrm{Na} / \mathrm{K} / \mathrm{Cl} / \mathrm{Fe} / \mathrm{Al} / \mathrm{Si} / \mathrm{O}$

5. $\mathrm{Fe} / \mathrm{K} / \mathrm{Cl} / \mathrm{C} / \mathrm{Si} / \mathrm{O}$

6. $\mathrm{K} / \mathrm{Al} / \mathrm{Si} / \mathrm{O}$

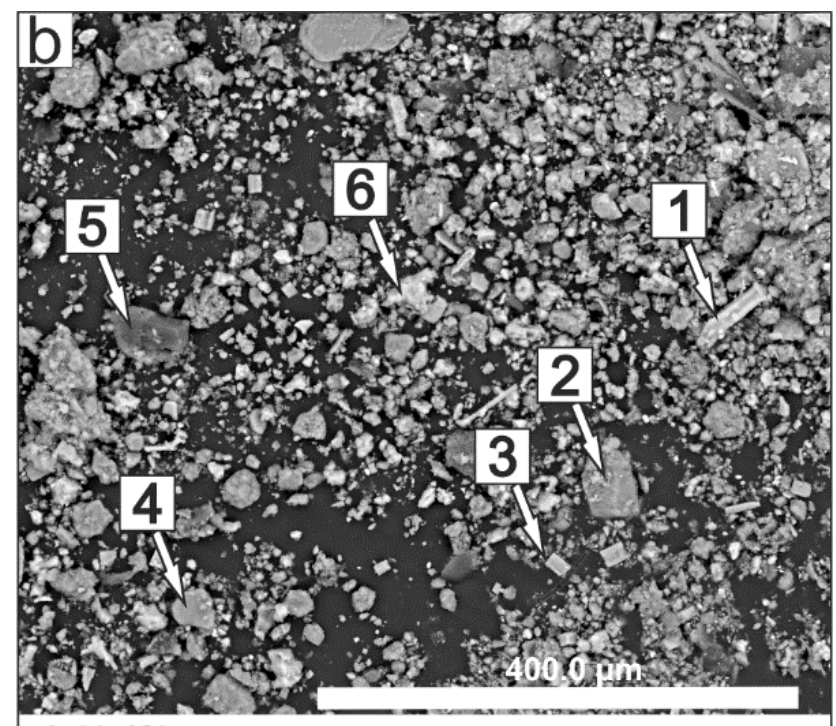

1. $\mathrm{Na} / \mathrm{Cl}$

2. $\mathrm{Si} / \mathrm{O}$

3. $\mathrm{Ca} / \mathrm{S} / \mathrm{O}$

4. $\mathrm{K} / \mathrm{Mg} / \mathrm{Fe} / \mathrm{Na} / \mathrm{Cl} / \mathrm{Al} / \mathrm{Si} / \mathrm{O}$

5. $\mathrm{C} / \mathrm{O}$

6. $\mathrm{Na} / \mathrm{Cl}$

Figure 4. SEM images and EDS chemical analyses of airborne particles deposited in the entrance zone, E.3 (a) and the mine interior, I.5 (b).

Various spherical particles composed of metal oxides (Figure 5a); aluminosilicate glass (Figure 5b); diatom particles (Figure 5c); fragments of irregular-shaped, probably organic particles rich in C (Figure $5 \mathrm{~d}$ ); shapeless material composed of $\mathrm{Ca}, \mathrm{Si}$, and $\mathrm{Al}$ oxides (Figure 5e); and ferruginous flakes (Figure 5f) were often encountered. Particle aggregates containing $\mathrm{Ca}, \mathrm{S}$, and $\mathrm{O}$, or plate-like crystals of Ca sulfates (Figure 6a), as well as agglomerates composed of densely compacted anhedral sulfate particles with $\mathrm{Na}$ and $\mathrm{Ca}$ (Figure $6 \mathrm{~b}$ ), were also found. Several particles composed of $\mathrm{NaCl}$ have strongly elongated or shapeless morphology (Figure $6 \mathrm{c}, \mathrm{d}$ ). Particles containing $\mathrm{Mg}$, S, and $\mathrm{O}$ form acicular crystals (Figure $6 \mathrm{~d}, \mathrm{e}$ ) or large agglomerates composed of fine anhedral crystals (Figure 6f). All of the abovementioned components in most cases were not detected in the mine interior, and are typical solely for the entrance zone. Representative EDS spectra of individual airborne particles settled in the entrance zone are shown in Figure S1 (Supplementary Materials). 

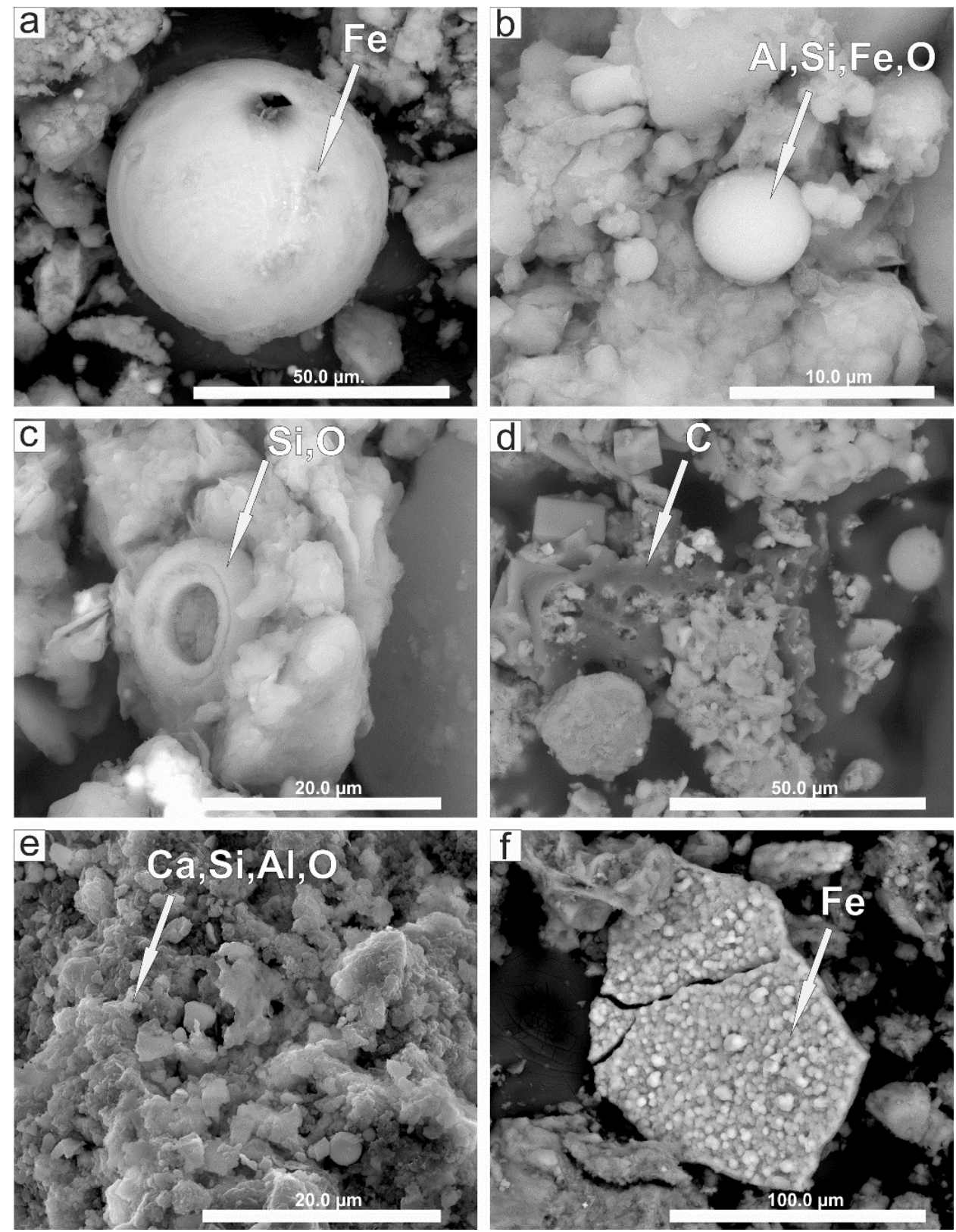

Figure 5. SEM images of individual airborne particles settled in the entrance zone. (a) Fe oxide spherule, E.2; (b) Al-Si-Fe oxide spherule, E.4; (c) diatom, E.2; (d) C-rich particle, E.2; (e) Ca-Al-Si-Orich material, E.3; (f) ferruginous flake, E.2.

In contrast to the entrance zone, the dust particles in the mine interior were more homogenous in size and composition. They were also smaller in size (Figure $4 \mathrm{~b}$ ). The dominant particles were smaller than $20 \mu \mathrm{m}$. They frequently formed angular individual grains. Individual Ca-S-O-rich particles rhombic or tabular in shape (Figure 7a) and cubic $\mathrm{NaCl}$ (Figure $7 \mathrm{~b}$ ) were most frequently observed. The mineral components containing $\mathrm{Al}, \mathrm{Si}, \mathrm{Ca}, \mathrm{Mg}, \mathrm{K}$, and $\mathrm{Fe}$, accompanied by various amounts of $\mathrm{Na}$ and $\mathrm{Cl}$, were also present. Moreover, $\mathrm{NaCl}$ particles of strongly elongated morphology were found; however, compared to these from the entrance zone, they showed different surfaces (Figure 7d). Very fine $\mathrm{Fe} / \mathrm{S}$ particles were also observed occasionally embedded in $\mathrm{Al} / \mathrm{Si} / \mathrm{O}$-rich matrix (Figure 7e). Various mineral components containing relatively high amounts of Fe were found, particularly often in site I.3 located on the underground railway route (Figure $7 \mathrm{f}$ ), metalliferous particles (Figure $7 \mathrm{~g}$ ), and iron oxide (Figure $7 \mathrm{~h}$ ). The samples from the mine located on tourist trails were also enriched with non-mineral, long fibrous, and flaky 
carbonaceous particles usually composed mostly of C (Figure 7h). Representative EDS spectra of individual airborne particles settled in the mine interior are shown in Figure S2.
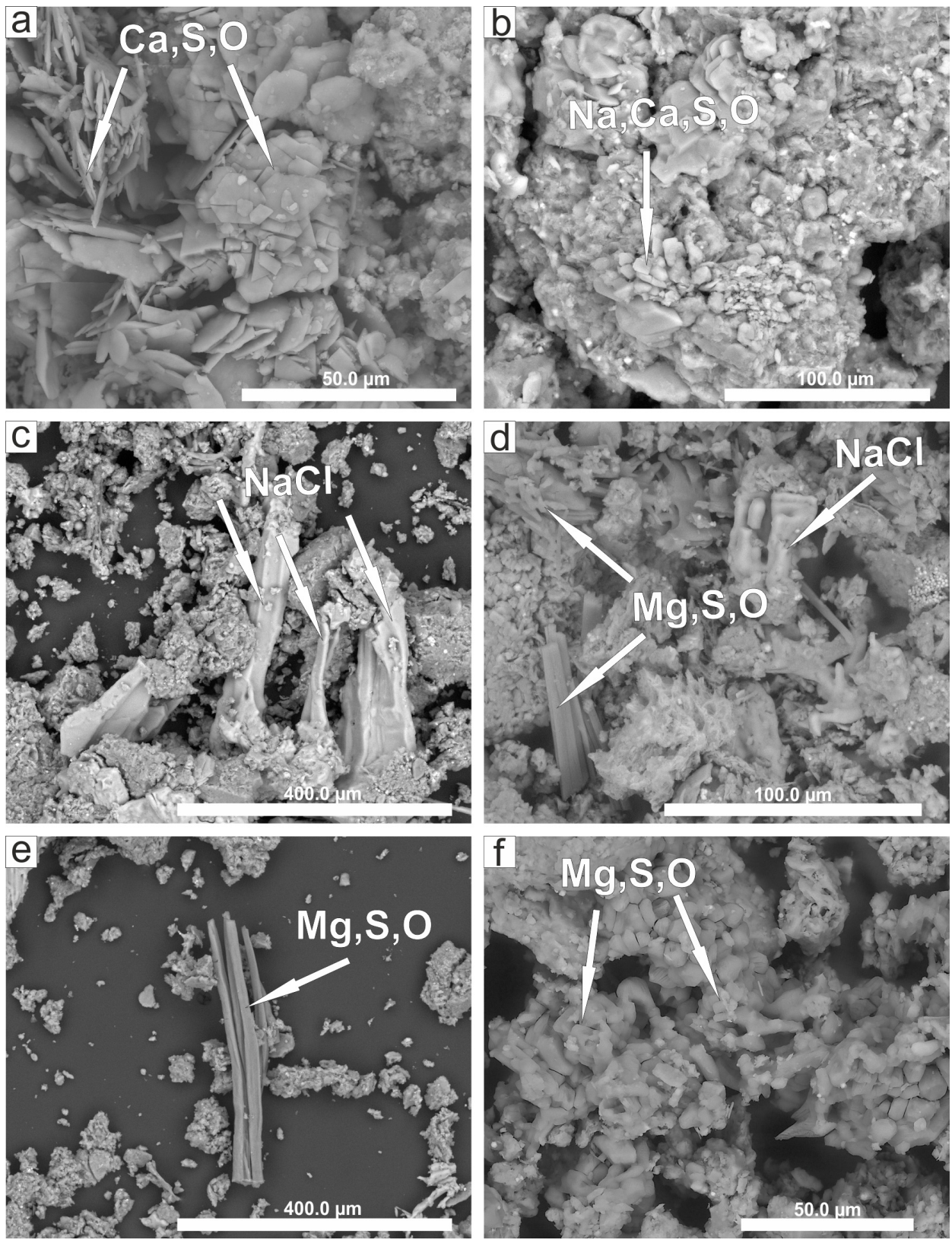

Figure 6. SEM images of individual airborne particles settled in the entrance zone. (a) Agglomerate of Ca-sulfates, E.2; (b) agglomerate of $\mathrm{Na}$ and Ca sulfates E.2; (c) NaCl particles, E.4; (d-f) various morphology of Mg-sulfate, E.3.

\subsection{Elemental Composition and Distribution \\ 3.3.1. Major Elements}

Distribution of major elements in airborne dust expressed as a percent of pseudo-total concentration is shown in Figure 8. The rank order of major elements in dust from site E.1 where ambient (outdoor) air was supplied to the mine was $\mathrm{Ca}>\mathrm{Al}>\mathrm{Na}>\mathrm{Fe}>\mathrm{S}>\mathrm{K}>\mathrm{Mg}$, while in most of the rest of the dust samples, it was $\mathrm{Na}>\mathrm{Ca}>\mathrm{Fe}>\mathrm{Al}>\mathrm{S}>\mathrm{Mg}>\mathrm{K}$ with two exceptions: Fe occurred in higher concentration than $\mathrm{Na}$ and $\mathrm{Ca}$ in site I.3, and exceptionally low content of $\mathrm{Na}$ was detected in a sample from site I.1. The content of individual components in the collected dusts exhibited higher variation at the beginning of the airflow to the mine than in the mine interior. 

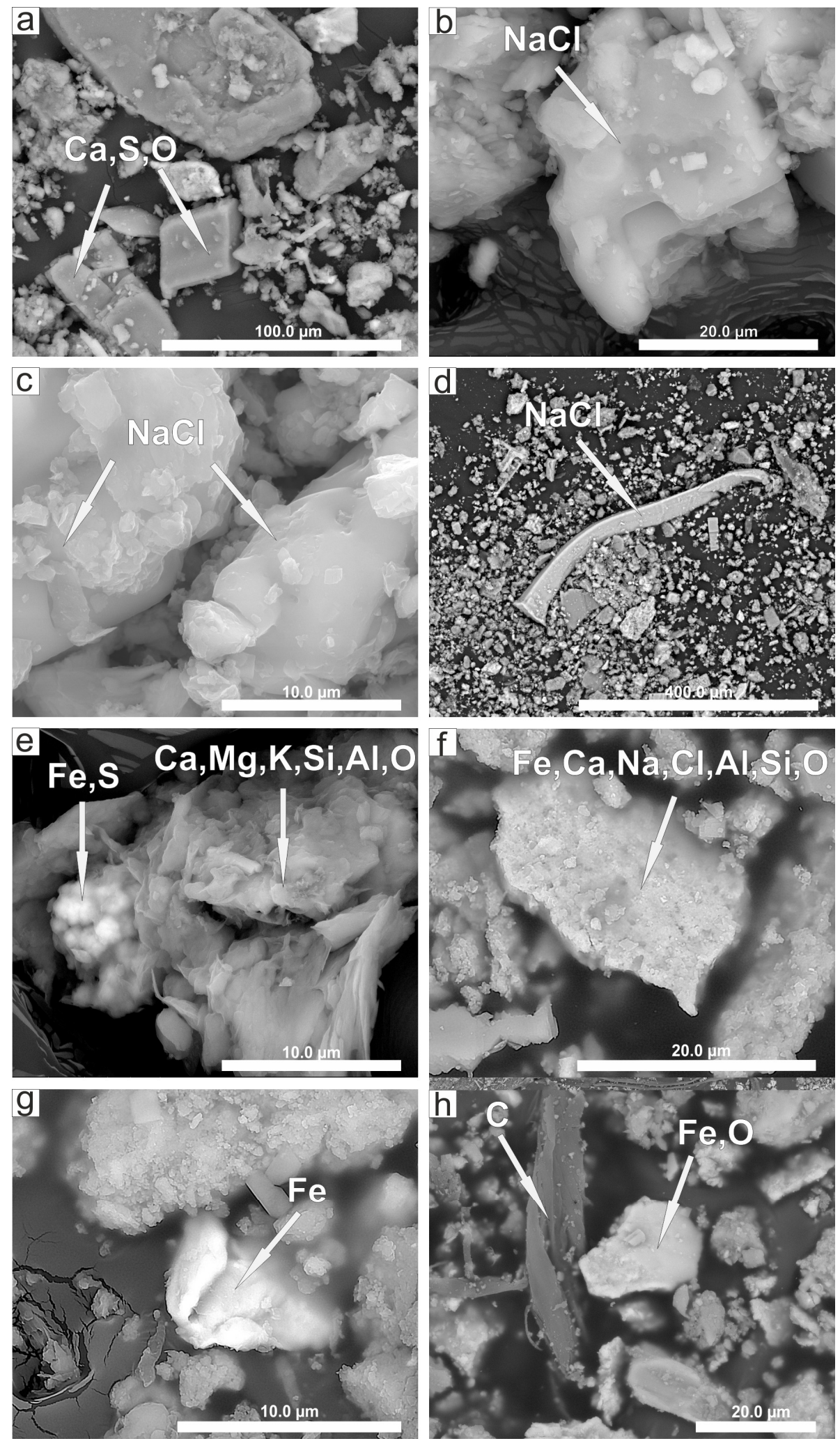

Figure 7. SEM images of individual airborne particles settled in the mine interior. (a) Ca-sulfate, I.7; (b) $\mathrm{NaCl}$ particle I.7; (c,d) $\mathrm{NaCl}$ particles, I.5; (e) Fe sulfide particles embedded in aluminosilicate matrix, I.7; (f) ferruginous material adhered to the surface of mineral agglomerates, I.3; (g) metalliferous particle, I.3; (h) iron oxide and carbonaceous flake, I.3. 


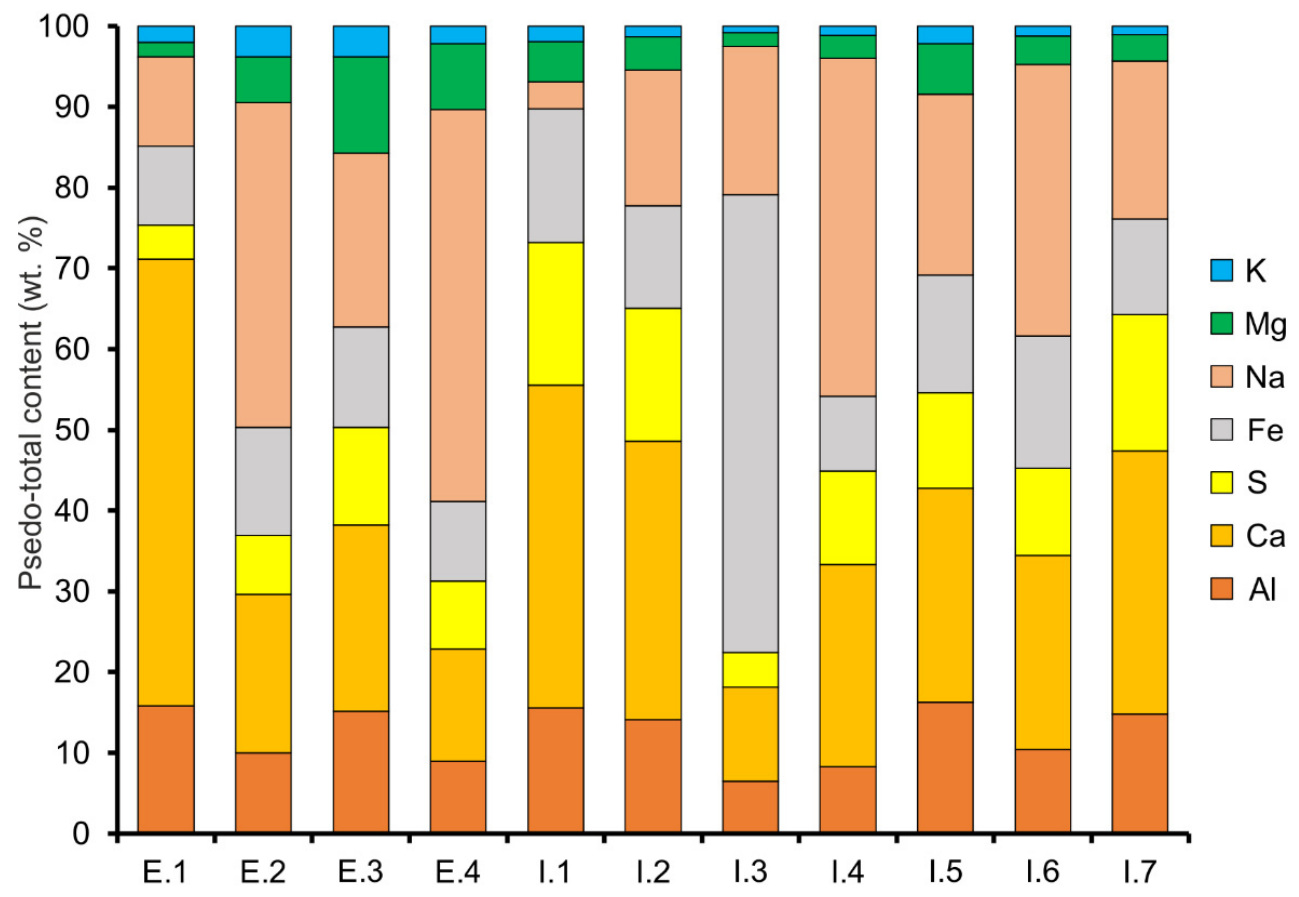

Figure 8. Mass percentage of major elements in dusts sampled at the consecutive sites.

Sodium ( $\mathrm{Na}$ ). The concentration of Na showed the most significant spatial variation across sampling sites. Similar to halite distribution, Na content increased at the beginning of atmospheric airflow in the mine: the maximum content of $\mathrm{Na}$ was measured at site E.4. At all locations in the mine interior (I.2-I.7), the Na content was higher than the values at site I.1.

Calcium ( $\mathrm{Ca}$ ). In contrast to the $\mathrm{Na}$ distribution, the concentration of $\mathrm{Ca}$ was the highest in the first sample (E.1) and reached the minimum value in the sample at the end of underground dust accumulation (E.4). At the next sampling site (I.1), it significantly increased, and relatively high Ca content, although in various proportions, was observed in most of the samples collected in the mine interior.

Iron $(F e)$. Fe concentrations showed general low variation across all sampling sites, except for site I.3 situated directly on the underground tourist railway, where a dominance of Fe was observed.

Aluminum ( $\mathrm{Al}$ ). The concentrations of $\mathrm{Al}$ varied across the sampling sites both in the mine entrance zone and in the mine interior. A correlated increase in $\mathrm{Al}$ and Ca content was observed in samples from the mine interior.

Sulfur (S). The concentration of S was the lowest at the first sampling site taken outdoors (E.1), and it increased along the atmospheric airflow in the mine. The maximum value of $\mathrm{S}$ content among the samples collected in the entrance zone was noted in site E.3. Similar to Ca distribution, $\mathrm{S}$ exhibited higher concentrations in the mine interior and a corresponding increase in $\mathrm{Ca}$ and $\mathrm{S}$ was noted.

Magnesium (Mg). Similar to $\mathrm{S}$ and $\mathrm{Ca}, \mathrm{Mg}$ showed an increase in concentration along the initial atmospheric airflow in the mine through the air inlet shaft and reached the maximum value in site E.3. Then, in contrast to all above-mentioned elements, its content gradually decreased toward the mine interior.

Potassium (K). The concentrations of $\mathrm{K}$ varied little across the sampling sites, showing slightly higher values in samples collected in the entrance zone.

\subsubsection{Minor Elements}

Analyzed minor elements (with concentration at the order of $0.2 \mathrm{wt} \%$ ) included: $\mathrm{P}, \mathrm{Mn}, \mathrm{Sr}$, and $\mathrm{Zn}$, while trace element presented concentrations below $0.02 \mathrm{wt} \%$. The distributions of minor elements are shown in Figure 9. The most abundant minor elements 
in most of the samples are $\mathrm{P}$ and $\mathrm{Mn}$. The overall content of minor elements was the highest at site I.3 (4646 mg/kg).

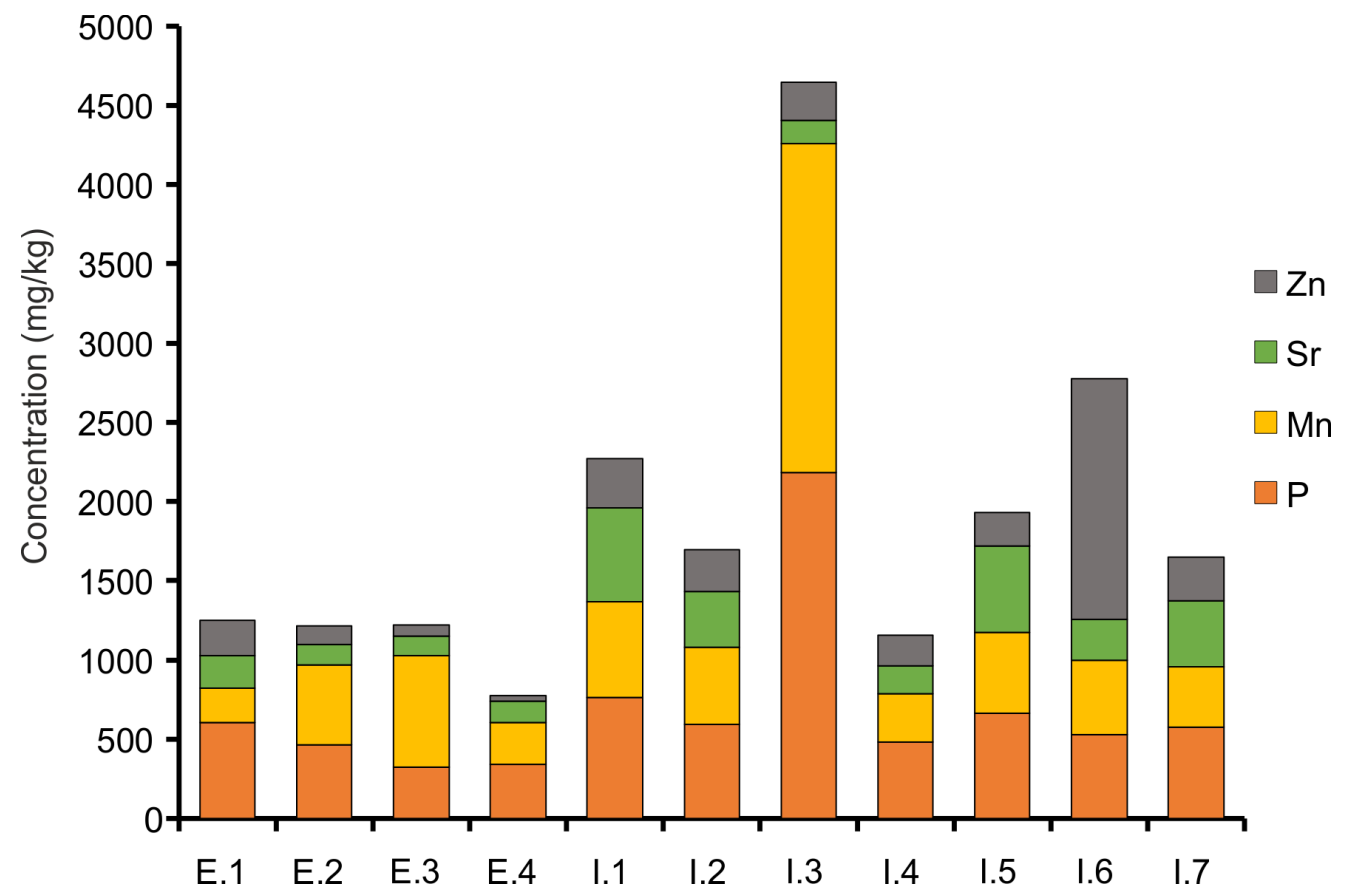

Figure 9. Minor elements concentrations in dusts sampled at the consecutive sites (in $\mathrm{mg} / \mathrm{kg}$ ).

Phosphorous $(P)$. The concentrations of $\mathrm{P}$ decreased from $607 \mathrm{mg} / \mathrm{kg}$ in the sample taken outdoors (E.1) to $309 \mathrm{mg} / \mathrm{kg}$ at the end of underground dust accumulation near the outlet air inlet shaft (E.4). At the subsequent sampling site (I.1) and in the most samples from the mine interior, the higher values were observed with content in the range of $483-761 \mathrm{mg} / \mathrm{kg}$. The exception was site I.3, where P concentration was over three times higher $(2186 \mathrm{mg} / \mathrm{kg})$.

Zinc $(\mathrm{Zn})$. The concentrations of $\mathrm{Zn}$ decreased $221 \mathrm{mg} / \mathrm{kg}$ in the sample taken outdoors (E.1) to $39.5 \mathrm{mg} / \mathrm{kg}$ at the end of underground dust accumulation near the outlet air inlet shaft (E.4). Higher values were observed in the samples from the mine interior with the highest content at site I.6 (1579 mg/kg). At the remaining sites of the mine inner zone, $\mathrm{Zn}$ concentration was at least five times lower.

Manganese (Mn). Similar to Fe, Mn concentration in the sample taken outdoors was lower $(214 \mathrm{mg} / \mathrm{kg})$ than in all samples collected in the mine. The concentration of $\mathrm{Mn}$ in the mine interior was relatively steady and ranged between 266 and $604 \mathrm{mg} / \mathrm{kg}$. The exception (similar to Fe and P) was site I.3, where the underground tourist railway is located: the highest concentration of Mn equal to $2071 \mathrm{mg} / \mathrm{kg}$ was measured at this site.

Strontium (Sr). The concentrations of Sr showed markedly lower values in the samples collected along the initial airflow path to the mine from site E.1 to E.4 (125-207 mg/kg). Beginning from site I.1, its concentration in the mine interior increased and showed significant variation in the range of $146-596 \mathrm{mg} / \mathrm{kg}$, indicating similar trends to Ca and S.

\subsubsection{Trace Elements}

The concentrations of trace elements in the deposited particles varied throughout the mine interior as well as in the entrance zone (Table 1). However, similar to the major and minor elements distribution, several trends in concentration, particularly at the beginning of the airflow to the mine, can be observed. For most of the trace elements, a decreasing trend of concentration with the distance from the ventilation shaft to the underground dust accumulation near the air inlet of the mine was observed. The concentrations of trace elements were always higher in samples taken outdoors (E.1) than at the end of dust 
accumulation in the entrance zone (E.4), with only a few exceptions of $\mathrm{Li}, \mathrm{Ni}, \mathrm{U}$, and $\mathrm{Ag}$. At the sampling site situated behind this dust accumulation (site I.1), the concentrations of trace elements followed the increasing trend of concentrations of other chemical and mineral components. However, extremely high concentrations of some heavy metals $(\mathrm{Cu}$, $\mathrm{Cr}, \mathrm{Ni}, \mathrm{Co}, \mathrm{Cd}, \mathrm{Mo}$, and Sn) were found in site $\mathrm{I} .3$, reaching $162 \mathrm{mg} / \mathrm{kg}, 110 \mathrm{mg} / \mathrm{kg}$, $66 \mathrm{mg} / \mathrm{kg}, 15 \mathrm{mg} / \mathrm{kg}, 13 \mathrm{mg} / \mathrm{kg}, 11 \mathrm{mg} / \mathrm{kg}$, and $8 \mathrm{mg} / \mathrm{kg}$, respectively. All other metals were considerably less abundant.

\subsection{Enrichment Factor}

The EF indices of sampling sites in the mine interior calculated with respect to ma-rine sediments are presented in Figure S3. In most of the studied sites in Bochnia Salt Mine, enrichment factors were below 1.5, indicating no enrichment or natural sources. However, in the dust sampled outdoors (E.1), the EF indices showed very high enrichment (20-40) in Ag and Cd, significant enrichment (5-20) in Sr, Zn, and moderate (2-5) in Rb and As. Dusts collected in in all samples from the mine interior (I.1-I.7) are characterized by high values of EF for Sr, $\mathrm{Zn}, \mathrm{Cd}$, and Ag. In addition, only dusts from two sampling sites located directly or near the tourist railway line (site I.3 and site I.6, respectively) show EF indices above 2 for selected metals. The EFs of metals in site I.3 were in the order of $\mathrm{Cd}>\mathrm{Sn}>\mathrm{Sb}>$ $\mathrm{Fe}>\mathrm{Zn}>\mathrm{P}>\mathrm{Cr}>\mathrm{As}>\mathrm{Cu}>\mathrm{Rb}$, while in site I.6, only $\mathrm{Zn}$ shows values much higher than those of the other sites.

The EF indices of sampling sites in the mine interior calculated with respect to local geochemical background concentrations (values from sampling site I.7) are presented in Figure 10. Although the EF indices for most of the samples showed no enrichment in the studied elements, they indicate a greater overall presence of metals than in the background. This is apparent particularly at sites I.3 and I.6. The magnitude of metal pollution yields the following ranking for the site I.3: $\mathrm{Fe}>\mathrm{Sn}>\mathrm{Cd}>\mathrm{Mn} \approx \mathrm{Mo}>\mathrm{Cr}>\mathrm{P}>\mathrm{Cu}>\mathrm{Co} \approx \mathrm{Ni} \approx$ $\mathrm{W}>\mathrm{As}>\mathrm{Sb}>\mathrm{Rb}>\mathrm{Pb}$. At site I.6, the ranking is different: $\mathrm{Zn}>\mathrm{Cu}>\mathrm{Sn}>\mathrm{Fe} \approx \mathrm{Mo} \approx \mathrm{As}$. In contrast to EFs calculated with respect to marine sediments, the EFs for $\mathrm{Sr}, \mathrm{Cd}, \mathrm{Ag}$, and Zn were lower than 1.5 in most of the sampling sites. In the dust sampled outdoors (E.1), the EF indices showed significant enrichment in $\mathrm{Ti}$ and moderate enrichment in $\mathrm{As}, \mathrm{Pb}$, and Zr. The EF indices for most of the metals showed the lowest values at the end of dust accumulation, with the few exceptions of $\mathrm{Fe}, \mathrm{Mn}, \mathrm{Li}, \mathrm{Ni}, \mathrm{U}, \mathrm{Hg}$, and $\mathrm{Ag}$.

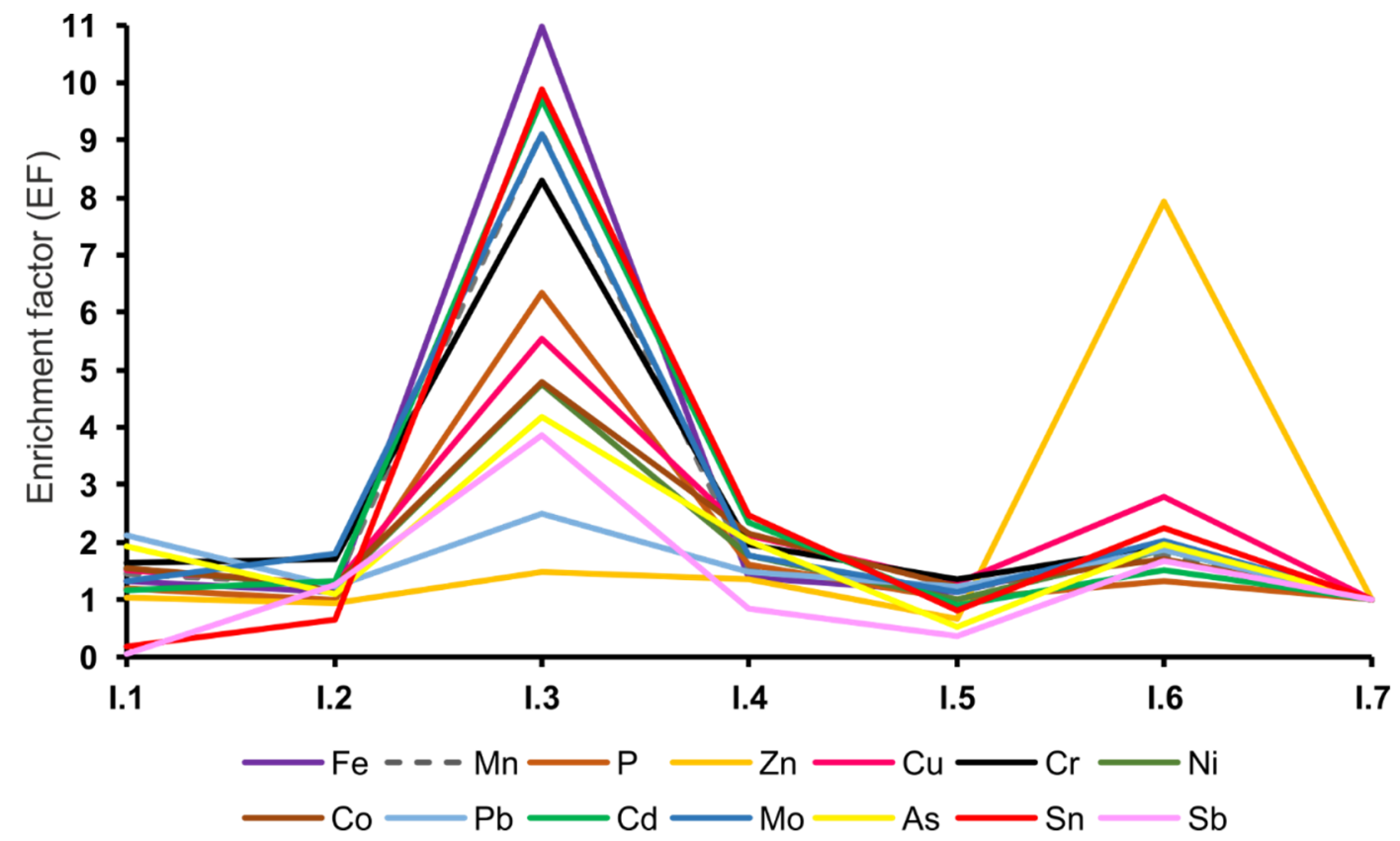

Figure 10. Enrichments factors (EFs) for metals in dusts collected in the mine interior with respect to local geochemical background concentrations from site I.7 (elements with low EFs values are not shown). 


\section{Discussion and Source Identification}

This work is one of the first to systematically evaluate the elemental and mineral composition of dust precipitation distributed along the atmospheric air stream from the initial air intake in a decommissioned salt mine open to the general public. In accordance with Puławska et al. [22], the results obtained in this study allowed us to distinguish three different sources of airborne particles within the underground mine: geogenic, anthropogenic, and biogenic particles. Although this study was performed in a salt mine, our sampling strategy and complementary analytical and statistical approaches, seem to have universal applicability in other subterranean environments.

\subsection{Natural Components from Host Rock}

\subsubsection{Distribution of Minerals}

The dusts sampled along the airflow path in increasing distance from the air inlet of the mine predominantly consisted of natural (geogenic) particles. The distribution of mineral components in samples from the mine interior (sites I.1-I.7) were markedly different from that from the entrance zone. The samples collected in the mine interior were characterized by a notable higher contents of three main minerals of $\mathrm{NaCl}$-rich ancient marine evaporates [58,59]: halite, anhydrite, and gypsum, accounting for an average of $67 \%$ of all crystalline phases in the dusts. However, the most prominent feature was the dominance of anhydrite, a mineral commonly encountered only in deeply buried evaporates in Poland [60]. In contrast to the entrance zone, Ca-sulfates (anhydrite and gypsum) present in the mine interior were most often in the form of well-shaped individual crystals, which confirms the dominance of deposit-driven origin (Figure 7a). Despite the fact that the host rock contains anhydrite rather than gypsum, all sampled dusts in the mine interior contained some traces of gypsum. This might be an effect of alteration of anhydrite to gypsum by reaction with air moisture. In shallow areas, favoring access to meteoric waters or in the underground space of high air moisture, secondary gypsum resulting from hydration of anhydrite is commonly found $[60,61]$. This is why exceptionally high content of gypsum was noted in site I.7, which is located in the shallower and, therefore, most waterlogged gallery [13].

The geogenic components present in the subsurface atmosphere are mainly derived from weathering and abrasion of the bedrock [22,42,62]. One would expect the dusts sampled within the salt mine to be strongly enriched in the most abundant mineral of the deposit-halite. However, most of the sampled dusts in the inner zone of the mine were heavily enriched with Ca-sulfate out of all proportions to its presence in the parent rock. The quantitative analysis of airborne halite underestimated the presence of halite, which is a very hygroscopic substance. Therefore, as a result of deliquescence in the moist air, $\mathrm{NaCl}$ enters the air aerosol partially in the form of droplets [22]. The SEM/EDS analyses revealed the presence of partially dissolved particles indicated by rounded edges of cubical or completely shapeless crystals of halite (Figure 7c). Therefore, the halite particles deposited in the mine are at least partially dissolved by high air moisture content and, consequently, escape the dust accumulation. SEM/EDS observations revealed that varying amounts of $\mathrm{Na}$ and $\mathrm{Cl}$ were also associated with many mineral agglomerates, indicating that these aggregates could be partly soaked with $\mathrm{NaCl}$-containing moisture (Figure $4 \mathrm{~b}$ ). This presence of $\mathrm{NaCl}$-rich moist aerosol in the air also results in commonly observed secondary precipitation of various forms of halite on the surface of mine casing. Particles indicating a unique form of secondary crystallization of halite as hair-like crystals were also found in the deposited dust (Figure 7d). Salty "hair" is occasionally encountered in salt mines and salt caves growing from bedrock surfaces and is very similar to those of calcite and/or gypsum reported from several caves in the world [63-65]. Its origin is explained partly by evaporation of capillary solution in locations with substantial airflow and, in the case of halite, by the evaporation of saline aerosols carried in the air [62].

The other mineral phases present in the dust from inside the mine were components of the clay rocks that accompany the salt deposit: quartz, illite, muscovite, albite, kaolinite, 
and chlorite. These mineral assemblages, frequently accompanied by some dolomite and calcite, are constituents of claystones and anhydrites in Miocene evaporates from the Carpathian region $[61,66,67]$. Therefore, the presence of these minerals in the dusts should be attributed to the claystone and anhydritic claystone intercalations commonly exposed on the walls of the Bochnia mine. The abundance of illite in the mine interior compared to its small amount in the entrance zone further supports the origin of these particles from the deposit. Illite is recognized as a stable mineral in a hypersaline environment, and, therefore, it is frequently found in various halite deposits [68].

The samples from the mine interior are characterized by low variability of mineral components. A significant difference in mineral composition is apparent only in the presence of the amorphous phase at site I.3. Other than that, relatively little change was found in the distribution of minerals across sampling points. Such small differences in dust composition in underground mines are generally linked to the dimensional pattern of the layers in the parent rocks [22,35]. However, in historic salt mines, this natural mineral distribution can be, to some extent, disturbed by maintenance and repair works [22,42].

Considering the above, it can be concluded that the mineral composition of the dusts occurring inside the mine was independent of the distance from the ventilation shaft and, thus, was not influenced by the particles sucked into the ventilation system of the mine. Instead, the mineral compositions of the investigated dusts inside the mine were, as expected, very close to the mineral composition of the parent deposit exposed in the mine pits. This suggests that the majority of the geogenic particles present in the inner zone undoubtedly originated from the parent rock. Other components are the result of indoor activities discussed in the sections below.

\subsubsection{Distribution of Elements}

The major elements composition of dust from the mine interior and their distribution corresponded to specific groups of minerals. The presence of major elements should be ascribed to the dominant minerals in the deposit (halite, Ca-sulfates, and clays) and, to a lesser extent, to minor mineral components (calcite and dolomite).

Previous studies in Bochnia mine demonstrated a strong dependence of the concentrations of $\mathrm{Mg}$ and $\mathrm{K}$ on the presence of insoluble fractions [69]. Therefore, these elements should be ascribed to clays (Mg also to dolomite). Similarly, the presence of Fe should also be attributed to these gangue rocks (except site I.3). The coexistence of Fe with various clay minerals and other aluminosilicates is well documented [70,71]. In addition, the natural origin of Fe in dusts can be in part explained by the occurrence of framboidal pyrite aggregates embedded into a clay matrix (Figure 7e). The amounts of pyrite, however, are very small, below the detection limit of XRD equal for pyrite to ca. $1 \mathrm{wt} . \%$.

All minor and trace elements found in the sampled dusts are ubiquitously present both within the crystals and in the fluid inclusions of modern and ancient evaporite minerals $[59,61,72-74]$. Indeed, the natural origin of most elements in most of the sampling sites in the mine interior was confirmed by calculated EF values below 1.5. However, salt rocks are rarely considered as main carriers of metals because their substation for $\mathrm{Na}^{+}$ions is very limited [75]. On the other hand, clay minerals are well known for their capability of accumulation of a variety of trace elements [76,77]. Moreover, Ca-sulfates are often enriched in $\mathrm{Sr}$ as a result of the isovalent substitution for $\mathrm{Ca}[61,72,78]$. Therefore, most of the minor and trace elements in the mine interior seem to be related to anhydrite and clastic sediments. This is probably why the calculated EF values normalized to the marine sediments showed significant enrichment for $\mathrm{Sr}$ in the mine interior $(\mathrm{EF}>5)$. Since anhydrite was the dominant mineral in the collected dusts, this anomaly is caused by the petrological and geochemical character of the Bochnia deposit rather than anthropogenic input. Similar to the major elements, several variations in the concentrations of minor and trace elements can be related to the mineral composition of the settled dust and may vary depending on the variable contribution of claystone sulfate intercalations in a particular site in the mine. Therefore, the reference values taken from the local background level seem to be 
more appropriate in evaluating the degree of potential anthropogenic contamination as it takes into consideration the particular geochemical character of this subterranean space. Those observations are in agreement with pollution assessments performed in other environments [79-81]. Additionally, the elevated EFs at site I.3 allowed for identification of local anthropogenic sources of selected elements, which are discussed below.

The lowest concentrations of most of the trace and minor elements were found at the end of underground dust accumulation, which indicate relatively fast air purification of suspended particles. A higher concentration of most of these elements in the next sampling site (I.1) was followed by the increased input of minerals from the deposit (anhydrite and clays), suggesting their natural origin. However, due to the short distance from the ventilation shaft (approximately $300 \mathrm{~m}$ ), the influence of external particles on dust from site I.1 cannot be ruled out.

\subsection{The Effect of Indoor Activities}

Although most of the elements present in the dust deposited in the mine can be attributed to a natural geogenic origin ( $\mathrm{EF}<1.5)$, the observed extreme values of some metals detected in the tourist zone of the mine undoubtedly indicate local anthropogenic emission sources. It was found that the concentrations of $\mathrm{Fe}, \mathrm{Mn}, \mathrm{Cd}$, and $\mathrm{Sn}$ at site I.2 were at least four times higher, and the concentrations of $\mathrm{P}, \mathrm{Cr}, \mathrm{Cu}, \mathrm{Mo}, \mathrm{Ni}, \mathrm{Co}$, and $\mathrm{Sb}$ were at least two times higher than at the preceding site I.2 located in front of the tourist zone (Table 1). These observations correspond to the elevated values of the enrichment indices (Figure 10). Additionally, dust collected at site I.6 was significantly enriched with $\mathrm{Zn}$ and moderately enriched with $\mathrm{Cu}, \mathrm{Sn}, \mathrm{Mo}$, As, and Fe.

The correlated significant increase in concentrations and EF values of these metals at site I.3, which is directly located on the underground railway route, indicates that this tourist attraction is a main emission source. The study performed in Postojna Cave (Slovenia) also indicated the railway as an important anthropogenic source of some heavy metals, namely, $\mathrm{Fe}, \mathrm{Mn}, \mathrm{Cu}$, and $\mathrm{Pb}$ [34]. These observations are also consistent with the study performed in underground subway systems in which most of these metals were ascribed to the wear and friction process of rails and wheels ( $\mathrm{Fe}, \mathrm{Mn}, \mathrm{Cr}, \mathrm{Sb}$, and $\mathrm{Rb}$ ) and brakes ( $\mathrm{Cu}, \mathrm{Sn}, \mathrm{Mo}, \mathrm{Pb}, \mathrm{Co}, \mathrm{Ni}, \mathrm{As}, \mathrm{Cd}, \mathrm{W}, \mathrm{Mn}$, and $\mathrm{Cr}$ ) [82]. The corresponding pollution with $\mathrm{P}$ of dust collected in site I.3 also suggests the same emission sources. As previous studies in the subway system revealed, these trace metallic particles are either embedded within ferruginous masses or adhered to the surface of larger particles $[83,84]$. This is in agreement with our SEM/EDS observations, which showed the presence of either individual particles of iron oxide (Figure $7 \mathrm{~h}$ ) and ferruginous material adhered to the surface of aluminosilicates (Figure 7f), with the latter being more abundant. However, no peaks from iron minerals were detected by XRD quantitative analysis, which suggested that all Fe-rich particles were accounted as amorphous material. In subway, ferruginous airborne particles are typically oxidized to Fe-oxide: magnetite $\left(\mathrm{Fe}_{2} \mathrm{O}_{4}\right)$, maghemite $(\gamma$ $\left.\mathrm{Fe}_{2} \mathrm{O}_{3}\right)$, and hematite $\left(\mathrm{Fe}_{2} \mathrm{O}_{3}\right)[83,85]$. In this study, additional XRD analyses of directly sampled corrosion products of rails revealed the presence of goethite $(\alpha-\mathrm{FeOOH})$ and akaganeite $(\beta-\mathrm{FeOOH})$. These two minerals were also found in rail rust from a subway system exposed to Cl-rich water leakage [86]. Samples collected from the iron mining support were, in addition to the aforementioned minerals, enriched in lawrencite $\left(\mathrm{FeCl}_{2}\right)$ and lepidocrocite $(\gamma$-FeOOH). The presence of magnetite, maghemite, and hematite cannot be ruled out since all abovementioned mineral assemblages are commonly encountered in iron-based metals from a salt mine environment [87]. This study also revealed the presence of no oxidized metalliferous particles in site I.3 (Figure 7g), most probably originating from a railway track.

It is worth noting that, at the subsequent sampling sites, the concentrations of these railway-related pollutants gradually decreased close to the background level (Table 1). The increase in $\mathrm{Zn}$ concentration at the sampling point I.6 could be referred to the corrosion of the galvanized steel pipes observed earlier in this area [22]. The gradual decrease in 
concentration, followed by decrease in the degree of pollution of dusts with the distance from the emission sources, suggests a self-purification process of the air within the mine by gravitational deposition. As the sampling site I.6 is situated about $200 \mathrm{~m}$ from the eastern end of the tourist railway line, the dust collected from there presented moderate enrichment with some metals related mainly to the brake emission $(\mathrm{Cu}, \mathrm{Sn}, \mathrm{Mo}$, and As). This might be due to the fine size of brake-related particles mentioned by other researchers $[83,88]$, which in turn might be enabled to the more distant transport in the mine. Still, the subsequent sampling site I.7 exhibited the lowest concentrations of most metals related to both the railway and mining machinery (Table 1). This confirmed that particle deposition within the mine ventilation system is relatively effective and fast. However, as shown by Minguillón et al. [89], concentrations of all these metals may vary depending on railway running frequency; the used type of rails, wheels, and brakes; and the different proportion of emissions from different sources (e.g., frequent braking). Furthermore, it is known that the degree of heavy metal contamination may vary depending on pollution indices, geochemical background, and reference elements [81,90]. Despite all these variables, they can be grouped broadly into internal anthropogenic sources linked to the underground tourist railway. Such a set of indicators of pollution related to underground train appears important in the light of the growing number of this kind of tourist attraction in subterranean space across the globe (see e.g., Strataca Mine, USA; Bex Mine, Switzerland; Sullivan Mine, Canada; Wolfstein Mine, Germany; and Khewra Mine, Pakistan).

In addition, SEM and EDS analyses revealed that the deposited dust in the mine interior contained fragments of hair, clothing, and skin (Figure 7h). These carbon-bearing amorphous particles of anthropogenic origin have been detected previously in suspended particles in the air in the areas of increased tourist traffic and activity in the Bochnia mine [22]. This kind of air pollutant is also subjected to the deposition process. These particles, along with the metalliferous particles, might have contributed to the presence of an amorphous phase in several samples situated in the tourist zone in the mine (sites I.3, I.5, and I.7). The problems of this kind of anthropogenic remains have been previously raised in the case of caves [91].

\subsection{The Effect of External Air Pollution}

A very significant accumulation of dust is observed in a mining excavation near the air inlet shaft (Figure 2). This kind of accumulation does not exist anywhere else in the mine. This suggests that the deposited particles are of external origin. Moreover, the mineral and chemical composition of dust collected in this area (sampling points E.1-E.4) differs in many respects from the composition of dust in the mine interior. All available evidence suggests that sources of mineral and chemical components of the dust deposit near the air inlet shaft include natural dust present in the ambient air on the surface, air pollution sucked from the surface into the mine (particulate matter and gaseous pollution), and particles shed from the deterioration of the lining of the air inlet shaft. This demonstrates both the significant influence of the composition of the outdoor air forced into the mine's ventilation system and the very effective air purification processes taking place in this part of the mine. Instantaneous deposition of significant amounts of dust in close vicinity to the air inlet in the mine occurs mainly for two reasons: due to the decrease in air speed and due to the strong humidity and temperature gradient, resulting in moisture condensation on the dust particles, which accelerates their settling.

The region of southern Poland has struggled with the problem of high concentrations of pollutants in the air for many years as shown by many papers, e.g., [92-94]. The reason for this is primarily the energy production based on coal (industrial and residential) as well as transportation and industrial emissions [95]. The air of Bochnia city, similarly to other relatively small cities of Kraków agglomeration and rural areas, is exposed to significant contamination emitted from residential burning of coal/wood, resulting in high emissions of particulate matter and gaseous pollutants $\left(\mathrm{SO}_{2}, \mathrm{CO}_{2}, \mathrm{NOx}\right)$, particularly in the heating 
season from October to March [96]. For proper ventilation of the underground system of the Bochnia Salt Mine, $25 \mathrm{~m}^{3} / \mathrm{s}$ of fresh air is required on average. Such a massive body of air forced by fans may incorporate ambient PM, which are then transported to the mine through the downcast shaft. In addition, the lining of the 210-m-long downcast shaft can become exposed to very different temperatures, pressures, moisture regimes, actions of aqueous solutions, and atmospheric gases, which can cause its slow structural deterioration $[97,98]$. The sampling sites E.2, E.3, E.4, and I.1 are situated in a pit that is excavated in claystone (Chodenice Bed) and claystone-sulfate rock (top anhydrite), not in the proper salt deposit (Figure 2). The presence of $\mathrm{NaCl}$ particles detected in the samples E.2, E.3, and E.4 results probably from the weathering of the brick walls of the shaft, which may contain $\mathrm{NaCl}$, and from the evaporation of water leaks infiltrating from behind the shaft lining. For many years, the Trinitatis shaft was used as an exhaust shaft. Only since 2004 has the direction of air circulation in the mine been reversed, and, since then, the shaft serves as the air inlet. This origin of $\mathrm{NaCl}$ particles was confirmed by SEM/EDS observation, which revealed that halite particles have considerably different morphology in the entrance zone than in the mine interior. Since in the next sampling site (I.1) only $1 \mathrm{wt} . \%$ of halite was detected, it can be concluded that these $\mathrm{NaCl}$ particles carried by the air after entering the mine are subjected to the relatively quick sedimentation in the entrance zone. The air inlet shaft is constantly exposed to high gradients of temperatures, extreme moisture regimes, and thus repetitive cycles of salt dissolution/crystallization. This, combined with substantial pressure of the forced airflow, could intensify the fracking and disaggregation of the lining. Most probably, the detached lining fragments were represented by large, highly weathered, irregular aggregates composed of a variety of elements, such as $\mathrm{Mg}$, $\mathrm{Ca}, \mathrm{Na}, \mathrm{K}, \mathrm{Fe}, \mathrm{Cl}, \mathrm{Al}, \mathrm{Si}$, and $\mathrm{O}$ (Figure $4 \mathrm{a}$ ) as well as shapeless aggregates of $\mathrm{Al}$ and $\mathrm{Si}$ oxides (Figure 5e). The ferruginous flakes (Figure 5f) most probably originated from metal elements of the shaft construction. These components have not been detected by XRD analysis contributing to the abundant amorphous phase found there (Figure 3).

The concept of entrance zone coarse aerosol deposition caused by progressive gravitational sedimentation as a result of the gradual reduction of airflow rate/velocity has been previously raised in the case of caves [63]. This study demonstrates that the same is observed in mechanically ventilated mines. Similar to the caves, the high RH in the mine might also play an additional role in this mechanism through the absorption of air moisture by the particles, which can result in an increase in their size, formation of large aggregates, and precipitation of sparingly soluble salts accelerating the deposition process. This is consistent with SEM observations, which clearly showed the dominance of large particles in the dusts near the entrance zone (Figure 4).

The dust from the outdoor sample (E.1) contained mostly natural components of atmospheric dusts: quartz, calcite, plagioclases, and other mineral components of soils. The presence of halite was also detected, which may have come from de-icing salt or brine, which are extensively used in winter on streets in Poland [99]. The dust collected at subsequent points in the mine also contained natural components (originating from underground excavations due to the to the lack of tightness in some parts of the old mining supports, e.g., gypsum, quartz, and aluminosilicates), and components indicating anthropogenic origin, transported as solid particles, or crystallizing as a result of the reaction of atmospheric components in the presence of moisture. The SEM-EDS analysis revealed the presence of $\mathrm{Mg}$ sulfate (epsomite $\mathrm{MgSO}_{4} \cdot 7 \mathrm{H}_{2} \mathrm{O}$ ) in the form of needle-like (Figure 6d,e) and densely compacted fine crystals (Figure 6f). Moreover, various particles of Ca sulfate and Na sulfate were observed (Figure $6 a, b$ ). These forms were very similar to those found in urban mortars and masonry exposed to air pollution [99,100] as well as those from laboratory sulfation experiments [101,102]. Acid gases potentially present in a polluted atmosphere can react with various components of building materials, causing various pathologies. In the presence of moisture, atmospheric acidic pollutants (e.g., $\mathrm{SO}_{2}$ ) are transformed into their respective acids (e.g., $\mathrm{H}_{2} \mathrm{SO}_{4}$ ), further reacting with building materials as briefly described in Morillas et al. [103]. This, in combination with the presence 
of cations $(\mathrm{Mg}, \mathrm{Ca}, \mathrm{Na})$ in the building material used for lining of the inlet shaft, might lead to the formation of various $\mathrm{Mg}, \mathrm{Ca}$, and $\mathrm{Na}$ sulfates [96]. The action of brine solutions and secondary crystallization of salts is recognized as one of the most important causes of deterioration endangering built heritage [103-105].

The research performed in the Wieliczka Salt Mine by Salmon et al. [42] demonstrated an almost complete loss of outdoor airborne sulfur in the high heating season at the very beginning of the underground air inlet to the mine. This was confirmed by the sulfur isotope data. The important role of atmospheric sulfur loss in the atmosphere of salt mines may provide the widely recognized neutralizing properties of halite described from various coastal regions [106-110]. In the polluted coastal zone, anthropogenic sulfuric acid or nitric acid reacts with sea salt $(\mathrm{NaCl})$ to form coarse particles of $\mathrm{NaNO}_{3}$ and $\mathrm{Na}_{2} \mathrm{SO}_{4}$, which increase the deposition velocity of airborne particles and clean the atmosphere from acidic gaseous aerosol precursors [106,111], which may be both crystalline and amorphous [112,113]. Such chemical compounds were also detected here in the dust settled near the air inlet shaft.

The presence of fly ash spherical particles (detected by SEM/EDS) is notable in the composition of dusts collected in the entrance zone (sample points E.1-E.4, Figures 4a and 5a,b). Their size decreased with the distance from the outlet of the air inlet shaft, which indicates the progressive gravitational sedimentation of external particles at the very beginning of the air entrance to the underground excavations. However, some individual fine aluminosilicate spheres may be transported and deposited further in the mine interior. They were sporadically observed in this, and in a previous study of PM from the Bochnia mine [22]. This type of air pollution resulting from industrial high-temperature processes is common in southern Poland. Particles of this type can be transported over a long distance from industrial plants [114-116]. Other type of particulate matter in the entrance zone includes char particles (Figure $5 \mathrm{~d}$ ), representing mostly urban air pollution resulting from unburned carbon particles formed during pyrolysis [117]. Numeral fragments of diatoms (Figure 5c) were also found, representing natural components of air dust often also recognized in the subterranean environment of caves [118]. All of these solids are responsible for the increased content of the amorphous components of samples collected in this area.

\section{Conclusions and Implications for Management}

The analytical methodology used in this work, combining XRD, SEM-EDS, ICP, and the pollution index $(\mathrm{EF})$, has proved to be a powerful analytical strategy to characterize the source and distribution of atmospheric dusts in an underground mine currently open to the general public as a museum and spa facility. The results emphasize the heterogeneity and diversity of the deposited particles and enabled us to distinguish between the natural and anthropogenic sources that contributed to the chemical and mineralogical composition of dust fallout inside the historic mine. Based on the morphological, mineralogical, and chemical characteristics of dusts collected in eleven different locations, arranged in the order of increasing distance from the air intake of the mine, the following observations were made:

1. The mechanical ventilation necessary for proper ventilation of extensive underground networks causes various airborne components of external origin to entry with a sucked fresh air stream to the underground atmosphere. These are natural geogenic and biogenic dust components, anthropogenic air pollution in the form of particulate matter and gaseous pollution, and particles from the deterioration of the lining of the downcast shaft. However, as a result of instantaneous sedimentation resulting from gradients in moisture, temperature, and airflow speed, these components are largely deposited underground in the close vicinity of the air inlet to the mine. This makes the air inside the mine much cleaner than the ambient air on the surface. Such effective air purification processes taking place at the very beginning of the air entrance zone seem to confirm the high potential of respiratory rehabilitation conducted in this kind of subterranean facility. 
2. The primary mineral constituents of the particles settled in the mine interior are natural materials derived from the weathering of the host rock. The mineral components present in the aerosols of the mine interior were not influenced by the particles sucked into the mine by the ventilation system. Biogenic allergens are missing as well as regular dust primarily composed of quartz sand and soil particles. The mineral composition of the dust in the mine interior is dominated by mineral components of local rocks: halite, anhydrite, and claystone. Their amount is small. Their properties, size, and morphology pose no risk to human health. The elemental composition and distribution of the elements in most of the samples taken along the airflow in the mine interior primarily correspond to geogenic sources. Additionally, the deposited dust in the mine interior contained anthropogenic particles of local origin (fragments of hair, clothing, skin, etc.) typical of indoor air pollution in public utility environments.

3. The tourist railroad and the associated tourist traffic are a local source of atmospheric dust components, which differ in their mineral and chemical composition from dusts found in other parts of the mine museum. This is because in the subway, various processes associated with the operation (wear and friction of the rails, wheels, and brakes and increased passenger traffic) are responsible for these emissions. The gravitational deposition of these pollutants causes rapid self-cleaning of the air and limits the effects of the emissions at the local range. On the other hand, deposition of these rust-colored contaminants on the surfaces of mine walls and museum artifacts (e.g., sculptures carved into salt rock) can adversely affect their natural and aesthetic values. Due to the relatively short exposure of visitors to this type of local contamination, there is no risk to people visiting the museum. However, rest or rehabilitation areas should be arranged in the mine at some distance from such attractions.

Supplementary Materials: The following are available online at https:/ / www.mdpi.com/article/10 $.3390 / \mathrm{min} 11070686 / \mathrm{s} 1$, Figure S1: representative EDS spectra of individual airborne particles settled in the entrance zone, Figure S2: representative EDS spectra of individual airborne particles settled in the mine interior, Figure S3: enrichments factors (EFs) for metals in dusts collected in the mine interior with respect to the marine sediments concentrations.

Author Contributions: Conceptualization, A.P. and M.M.; methodology, A.P. and M.M.; formal analysis, A.P. and M.M.; investigation, A.P., M.M., M.F.; resources, A.P. and M.M.; data curation, A.P.; writing—original draft preparation, A.P.; writing—review and editing, M.M.; visualization, M.F.; supervision, M.M.; project administration, A.P.; funding acquisition, A.P. and M.M. All authors have read and agreed to the published version of the manuscript.

Funding: Financial support for the research was provided by the Polish Ministry of Science and Higher Education, grant no. 30/DW/2017/01/1 under the "Implementation Doctorates" program.

Data Availability Statement: Not applicable.

Acknowledgments: We thank three anonymous experts for their detailed reviews and help provided during the editorial process that helped us to improve the manuscript.

Conflicts of Interest: The authors declare no conflict of interest.

\section{References}

1. Kara, M.; Dumanoglu, Y.; Altiok, H.; Elbir, T.; Odabasi, M.; Bayram, A. Seasonal and spatial variations of atmospheric trace elemental deposition in the Aliaga industrial region, Turkey. Atmos. Res. 2014, 149, 204-216. [CrossRef]

2. Wawer, M.; Magiera, T.; Jabłońska, M.; Kowalska, J.; Rachwał, M. Geochemical characteristics of solid particles deposited on experimental plots established for traffic pollution monitoring in different countries. Chemosphere 2020, 260, 127575. [CrossRef] [PubMed]

3. Brimblecombe, P.; Thickett, D.; Yoon, Y.H. The cementation of coarse dust to indoor surfaces. J. Cult. Heritage 2009, 10, 410-414. [CrossRef]

4. Marcotte, S.; Estel, L.; Minchin, S.; Leboucher, S.; Le Meur, S. Monitoring of lead, arsenic and mercury in the indoor air and settled dust in the Natural History Museum of Rouen (France). Atmos. Pollut. Res. 2017, 8, 483-489. [CrossRef]

5. Uring, P.; Chabas, A.; Alfaro, S. Dust deposition on textile and its evolution in indoor cultural heritage. Eur. Phys. J. Plus 2019, 134, 255. [CrossRef] 
6. Shi, T.; Wang, Y. Heavy metals in indoor dust: Spatial distribution, influencing factors, and potential health risks. Sci. Total Environ. 2021, 755, 142367. [CrossRef]

7. Pérez-Álvarez, R.; Torres-Ortega, S.; Díaz-Simal, P.; Husillos-Rodríguez, R.; De Luis-Ruiz, J.M. Economic Valuation of Mining Heritage from a Recreational Approach: Application to the Case of El Soplao Cave in Spain (Geosite UR004). Sustainability 2016, 8, 185. [CrossRef]

8. Caamaño-Franco, I.; Suárez, M.A. The Value Assessment and Planning of Industrial Mining Heritage as a Tourism Attraction: The Case of Las Médulas Cultural Space. Land 2020, 9, 404. [CrossRef]

9. Saiz-Jimenez, C.; Cuezva, S.; Jurado, V.; Fernandez-Cortes, A.; Porca, E.; Benavente, D.; Cañaveras, J.C.; Sanchez-Moral, S. Paleolithic art in peril: Policy and science collide at Altamira Cave. Science 2011, 334, 42-43. [CrossRef]

10. Telbisz, T.; Gruber, P.; Mari, L.; Kőszegi, M.; Bottlik, Z.; Standovár, T. Geological heritage, geotourism and local development in Aggtelek National Park (NE Hungary). Geoheritage 2020, 12, 5. [CrossRef]

11. Festi, D.; Brandner, D.; Grabner, M.; Knierzinger, W.; Reschreiter, H.; Kowarik, K. 3500 years of environmental sustainability in the large-scale alpine mining district of Hallstatt, Austria. J. Archaeolog. Sci. Rep. 2021, 35, 102768. [CrossRef]

12. Voudouris, P.; Melfos, V.; Mavrogonatos, C.; Photiades, A.; Moraiti, E.; Rieck, B.; Kolitsch, U.; Tarantola, A.; Scheffer, C.; Morin, D.; et al. The Lavrion Mines: A Unique Site of Geological and Mineralogical Heritage. Minerals 2021, 11, 76. [CrossRef]

13. Puławska, A.; Manecki, M.; Flasza, M.; Waluś, E.; Wojtowicz, K. Rare Occurrence of Mirabilite in the Thirteenth-Century Historic Salt Mine in Bochnia (Poland): Characterisation, Preservation, and Geotourism. Geoheritage 2021, 13, 36. [CrossRef]

14. Trofimova, E.; Trofimov, A. World Subterranean Heritage. Geoheritage 2019, 11, 1113-1131. [CrossRef]

15. Madziarz, M. Historical ore mining sites in Lower Silesia (Poland) as geo-tourism attraction. Acta Geoturistica 2013, 4, 15-26.

16. Marescotti, P.; Brancucci, G.; Sasso, G.; Solimano, M.; Marin, V.; Muzio, C.; Salmona, P. Geoheritage Values and Environmental Issues of Derelict Mines: Examples from the Sulfide Mines of Gromolo and Petronio Valleys (Eastern Liguria, Italy). Minerals 2018, 8, 229. [CrossRef]

17. Costa, E.; Dino, G.A.; Benna, P.; Benna, P.; Rossetti, P. The Traversella Mining Site as Piemonte Geosite. Geoheritage 2019, 11, 55-70. [CrossRef]

18. Kazanc1, N.; Suludere, Y.; Özgüneylioğlu, A.; Mülazımoğlu, N.S.; Şaroğlu, F.; Mengi, H.; Boyraz-Aslan, S.; Gürbüz, E.; Yücel, T.O.; Ersöz, M.; et al. Mining Heritage and Relevant Geosites as Possible Instruments for Sustainable Development of Miner Towns in Turkey. Geoheritage 2019, 11, 1267-1276. [CrossRef]

19. Carrión-Mero, P.; Loor-Oporto, O.; Andrade-Ríos, H.; Herrera-Franco, G.; Morante-Carballo, F.; Jaya-Montalvo, M.; AguilarAguilar, M.; Torres-Peña, K.; Berrezueta, E. Quantitative and Qualitative Assessment of the "El Sexmo" Tourist Gold Mine (Zaruma, Ecuador) as A Geosite and Mining Site. Resources 2020, 9, 28. [CrossRef]

20. Freidl, J.; Huber, D.; Braunschmid, H.; Romodow, C.; Pichler, C.; Weisböck-Erdheim, R.; Mayr, M.; Hartl, A. Winter Exercise and Speleotherapy for Allergy and Asthma: A Randomized Controlled Clinical Trial. J. Clin. Med. 2020, 9, 3311. [CrossRef] [PubMed]

21. Kostrzon, M.; Sliwka, A.; Wloch, T.; Szpunar, M.; Ankowska, D.; Nowobilski, R. Subterranean Pulmonary Rehabilitation in Chronic Obstructive Pulmonary Disease. In Advances in Biomedicine. Advances in Experimental Medicine and Biology; Springer: Cham, Switzerland, 2019; Volume 1176, pp. 35-46. [CrossRef]

22. Puławska, A.; Manecki, M.; Flasza, M.; Styszko, K. Origin, distribution, and perspective health benefits of particulate matter in the air of underground salt mine: A case study from Bochnia, Poland. Environ. Geochem. Health 2021, 1-24. [CrossRef]

23. Lang, M.; Faimon, J.; Pracný, P.; Kejíková, S. A show cave management: Anthropogenic $\mathrm{CO}_{2}$ in atmosphere of Výpustek Cave (Moravian Karst, Czech Republic). J. Nat. Conserv. 2017, 35, 40-52. [CrossRef]

24. Liñán, C.; del Rosal, Y.; Carrasco, F.; Vadillo, I.; Benavente, J.; Ojeda, L. Highlighting the importance of transitional ventilation regimes in the management of Mediterranean show caves (Nerja-Pintada system, southern Spain). Sci. Total Environ. 2018, 631, 1268-1278. [CrossRef] [PubMed]

25. Myszkowska, D.; Kostrzon, M.; Dyga, W.; Kędzierska, J.; Namysł, M.; Stanisz, A.; Zagórska, M.; Ziemianin, M.; Obtułowicz, K.; Czarnobilska, E. Bioaerosol of salt chambers in the 'Wieliczka' Salt Mine, Poland. Aerobiologia 2019, 35, 297-311. [CrossRef]

26. Górny, R.L.; Frączek, K.; Ropek, D.R. Size distribution of microbial aerosols in overground and subterranean treatment chambers at health resorts. J. Environ. Health. Sci. Engineer. 2020, 18, 1437-1450. [CrossRef]

27. Mulec, J.; Oarga-Mulec, A.; Šturm, S.; Tomazin, R.; Matos, T. Spacio-Temporal Distribution and Tourist Impact on Airborne Bacteria in a Cave (Škocjan Caves, Slovenia). Diversity 2017, 9, 28. [CrossRef]

28. Wlazło, Ł.; Kasela, M.; Nowakowicz-Dębek, B.; Ossowski, M.; Malm, A. Bioaerosols in an Underground Tourist Trail. Pol. J. Environ. Stud. 2020, 29, 3865-3872. [CrossRef]

29. Grgić, I.; Iskra, I.; Podkrajšek, B.; \& Gerjevič, V.B. Measurements of aerosol particles in the Škocjan Caves, Slovenia. Environ. Sci. Pollut. R. 2014, 21, 1915-1923. [CrossRef]

30. Smith, A.C.; Wynn, P.M.; Barker, P.A. Natural and anthropogenic factors which influence aerosol distribution in Ingleborough Show Cave, UK. Int. J. Speleol. 2012, 42, 49-56. [CrossRef]

31. Tanda, S.; Licbinsky, R.; Hegrova, J.; Faimon, J.; Goessler, W. Arsenic speciation in aerosols of a respiratory therapeutic cave: A first approach to study arsenicals in ultrafine particles. Sci. Total Environ. 2019, 651, 1839-1848. [CrossRef] [PubMed]

32. Ličbinský, R.; Faimon, J.; Tanda, S.; Hegrova, J.; Goessler, W.; Uberhuberova, J. Changes in the elemental composition of particulate matter in a speleotherapeutic cave. Atmos. Pollut. Res. 2020, 11, 1142-1154. [CrossRef] 
33. Salmon, L.G.; Christoforou, C.S.; Gerk, T.J.; Cass, G.R.; Cassucio, G.S.; Cooke, G.A.; Leger, M.; Olmez, I. Source contributions to airborne particle deposition at the Yungang Grottoes, China. Sci. Total Environ. 1995, 167, 33-47. [CrossRef]

34. Muri, G.; Jovičić, A.; Mihevc, A. Source assessment of deposited particles in a Slovenian show cave (Postojnska jama): Evidence of long-lasting anthropogenic impact. Int. J. Speleol. 2013, 42, 225-233. [CrossRef]

35. Trechera, P.; Moreno, T.; Córdoba, P.; Moreno, N.; Zhuang, X.; Li, B.; Li, J.; Shangguan, Y.; Kandler, K.; Dominguez, A.O.; et al. Mineralogy, geochemistry and toxicity of size-segregated respirable deposited dust in underground coal mines. J. Hazard. Mater. 2020, 399, 122935. [CrossRef] [PubMed]

36. Mulec, J. Human impact on underground cultural and natural heritage sites, biological parameters of monitoring and remediation actions for insensitive surfaces: Case of Slovenian show caves. J. Nat. Conserv. 2014, 22, 132-141. [CrossRef]

37. Ravbar, N.; Šebela, S. The effectiveness of protection policies and legislative framework with special regard to karst landscapes: Insights from Slovenia. Environ. Sci. Policy 2015, 51, 106-116. [CrossRef]

38. Tičar, J.; Tomić, N.; Berg Valjavec, M.; Zorn, M.; Marković, S.B.; Gavrilov, M.B. Speleotourism in Slovenia: Balancing between mass tourism and geoheritage protection. Open Geosci. 2018, 10, 344-357. [CrossRef]

39. Brandi, I.; Barbosa, M.; Guimarães de Paula, R.; Araújo, R.; Vieira de Moura, R.; Mota de Lima, H. Instrumented geotechnical monitoring of a natural cave in a near mine operation-Towards a sustainable approach to mining and preservation of speleological heritage. J. Clean. Prod. 2019, 239, 118040. [CrossRef]

40. Liu, J.F.; Ma, T.F.; Liu, Y.L.; Zou, J.; Gao, M.Z.; Zhang, R.; Wu, J.; Liu, S.X.; Xie, H.P. History, advancements, and perspective of biological research in deep-underground laboratories: A brief review. Environ. Int. 2018, 120, 207-214. [CrossRef]

41. Xie, H.; Zhao, J.W.; Zhou, H.W.; Ren, S.H.; Zhang, R.X. Secondary utilizations and perspectives of mined underground space. Tunn. Undergr. Space Technol. 2020, 96, 103129. [CrossRef]

42. Salmon, L.G.; Cass, G.R.; Kozłowski, R.; Hejda, A.; Spiker, E.C.; Bates, A.L. Air Pollutant Intrusion into the Wieliczka Salt Mine. Environ. Sci. Technol. 1996, 30, 872-880. [CrossRef]

43. Wiewiórka, J.; Dudek, K.; Charkot, J.; Gonera, M. Natural and historic heritage of the Bochnia salt mine (South Poland). Studia UBB Geol. 2009, 54, 43-47. [CrossRef]

44. Peryt, D.; Gedl, P.; Peryt, T.M. Marine transgression(s) to evaporite basin: The case of middle Miocene (Badenian) gypsum in the Central Paratethys, SE Poland. J. Palaeogeogr. 2020, 9, 16. [CrossRef]

45. Garlicki, A. Salt Mines at Bochnia and Wieliczka. Przeglad Geol. 2008, 56, 663-669.

46. Poborski, J. The Bochnia salt deposit on the geological background of region. Biul. Państwowego Inst. Geol. 1952, 78, 3-160, (In Polish with English Summary).

47. Garlicki, A. Sedimentation of Miocene Salts in Poland. Pr. Geol. PAN 1979, 119, 1-67, (In Polish with English Summary).

48. Burliga, S.; Krzywiec, P.; Dabbroś, K.; Przybyło, J.; Włodarczyk, E.; Źróbek, M.; Słotwiński, M. Salt tectonics in front of the Outer Carpathian thrust wedge in the Wieliczka area (S Poland) and its exposure in the underground salt mine. Geol. Geophys. Environ. 2018, 44, 71-90. [CrossRef]

49. Marciniak, H.; Diduszko, R.; Kozak, M. XRAYAN_Program. Do Rentgenowskiej Analizy Fazowej; KOMA: Warszawa, Poland, 2006. (In Polish)

50. Loska, K.; Wiechula, D.; Korus, I. Metal contamination of farming soils affected by industry. Environ. Int. 2004, 30, 159-165. [CrossRef]

51. Peña-Icart, M.; Pereira-Filho, E.R.; Lopes Fialho, L.; Nóbrega, J.A.; Alonso-Hernández, C.; Bolaños-Alvarez, Y.; Pomares-Alfonso, M.S. Combining contamination indexes, sediment quality guidelines and multivariate data analysis for metal pollution assessment in marine sediments of Cienfuegos Bay, Cuba. Chemosphere 2017, 168, 1267-1276. [CrossRef] [PubMed]

52. Xu, F.J.; Hu, B.; Dou, Y.G.; Song, Z.J.; Liu, X.T.; Yuan, S.Q.; Sun, Z.L.; Li, A.C.; Yin, X.B. Prehistoric heavy metal pollution on the continental shelf off Hainan Island, South China Sea: From natural to anthropogenic impacts around 4.0 kyr BP. Holocene 2018, 28, 455-463. [CrossRef]

53. Liu, J.; Yin, P.; Chen, X.; Cao, K. Distribution, Enrichment and Transport of Trace Metals in Sediments from the Dagu River Estuary in the Jiaozhou Bay, Qingdao, China. Minerals 2019, 9, 545. [CrossRef]

54. Turekian, K.; Wedepohl, K. Distribution of the elements in some major units of the Earths crust. Geol. Soc. Am. Bull. 1961, 72, 175-192. [CrossRef]

55. Kowalska, J.; Mazurek, R.; Gasiorek, M.; Zaleski, T. Pollution indices as useful tools for the comprehensive evaluation of the degree of soil contamination-A review. Environ. Geochem. Health 2018, 40, 2395-2420. [CrossRef] [PubMed]

56. Sutherland, R.A. Bed sediment-associated trace metals in an urban stream, Oahu, Hawaii. Environ. Geol. 2000, 39, 611-627. [CrossRef]

57. Zhang, J.; Liu, C. Riverine Composition and Estuarine Geochemistry of Particulate Metals in China-Weathering Features, Anthropogenic Impact and Chemical Fluxes. Estuarine Coast. Shelf Sci. 2002, 54, 1051-1070. [CrossRef]

58. Warren, J.K. Evaporites through time: Tectonic, climatic and eustatic controls in marine and nonmarine deposits. Earth-Sci. Rev. 2010, 98, 217-268. [CrossRef]

59. Babel, M.; Schreiber, B.C. Geochemistry of evaporites and evolution of seawater. In Treatise on Geochemistry, 2nd ed.; Holland, H.D., Turekian, K.K., Eds.; Elsevier: Amsterdam, The Netherlands, 2014; pp. 483-560. [CrossRef]

60. Kasprzyk, A. Sedimentological and diagenetic patterns of anhydrite deposits in the Badenian evaporite basin of the Carpathian Foredeep, southern Poland. Sediment. Geol. 2003, 158, 167-194. [CrossRef] 
61. Jarzyna, A.; Bąbel, M.; Ługowski, D.; Vladi, F.; Yatsyshyn, A.; Olszewska-Nejbert, D.; Nejbert, K.; Bogucki, A. Unique Hydration Caves and Recommended Photogrammetric Methods for Their Documentation. Geoheritage 2020, 12, 27. [CrossRef]

62. Dredge, J.; Fairchild, I.J.; Harrison, R.M.; Fernandez-Cortes, A.; Sanchez-Moral, S.; Jurado, V.; Gunn, J.; Smith, A.; Spotl, C.; Mattey, D.; et al. Cave aerosols: Distribution and contribution to speleothem geochemistry. Quat. Sci. Rev. 2013, 63, 23-41. [CrossRef]

63. Forti, P. Chemical deposits in evaporite caves: An overview. Int. J. Speleol. 2017, 46, 109-135. [CrossRef]

64. Filippi, M.; Bruthans, J.; Palatinus, L.; Zare, M.; Asadi, N. Secondary halite deposits in the Iranian salt karst: General description and origin. Int. J. Speleol. 2011, 40, 141-162. [CrossRef]

65. Sawłowicz, Z.; Przybyło, J.; Boron, K. Colourful speleothems in the Wieliczka Salt Mine. Geol. Quart. 2014, 58, 449-458. [CrossRef]

66. Środon, J. Mixed-layer illite-smectite in low-temperature diagenesis: Data from the Miocene of the Carpathian Foredeep. Clay Miner. 1984, 19, 205-215. [CrossRef]

67. Jasionowski, M.; Peryt, T.M. Isotopic composition of dolomite associated with Middle Miocene Badenian anhydrites in the Carpathian Foredeep Basin of SE Poland. Geol. Quart. 2010, 54, 533-548.

68. Yaremchuk, Y.; Hryniv, S.; Peryt, T.; Vovnyuk, S.; Meng, F. Controls on Associations of Clay Minerals in Phanerozoic Evaporite Formations: An Overview. Minerals 2020, 10, 974. [CrossRef]

69. Toboła, T. Study of potassium and magnesium contents in salt deposit Bochnia (Southern Poland). Przeglad Geol. 2000, 48, 688-693.

70. Taitel-Goldman, N.; Ezersky, V.; Mogilyanski, D. High-resolution transmission electron microscopy study of Fe-Mn oxides in the hydrothermal sediments of the Red Sea deeps system. Clays Clay Miner. 2009, 57, 465-475. [CrossRef]

71. Engelbrecht, J.P.; Moosmüller, H.; Pincock, S.; Jayanty, R.K.M.; Lersch, T.; Casuccio, G. Mineralogical, chemical, morphological, and optical. Atmos. Chem. Phys. 2016, 16, 10809-10830. [CrossRef]

72. Leslie, A.B.; Harwood, G.M.; Kendall, A.C. Geochemical variations within a laminated evaporite deposit: Evidence for brine composition during formation of the Permian Castile Formation, Texas and New Mexico, USA. Sediment. Geol. 1997, 110, 223-235. [CrossRef]

73. Karavoltsos, S.; Sakellari, A.; Bakeas, E.; Bekiaris, G.; Plavšić, M.; Proestos, C.; Zinelis, S.; Koukoulakis, K.; Diakos, I.; Dassenakis, M.; et al. Trace elements, polycyclic aromatic hydrocarbons, mineral composition, and FT-IR characterization of unrefined sea and rock salts: Environmental interactions. Environ. Sci. Pollut. Res. 2020, 27, 10857-10868. [CrossRef]

74. Bukowski, K.; Galamay, A.; Krzywiec, P.; Maksym, A. Geochemical Data and Fluid Inclusion Study of the Middle Miocene Halite from Deep Borehole Huwniki-1, Situated in the Inner Zone of the Carpathian Foredeep in Poland. Minerals 2020, 10, 1113. [CrossRef]

75. Toboła, T.; Kukiałka, P. The Lotsberg Salt Formation in Central Alberta (Canada)—Petrology, Geochemistry, and Fluid Inclusions. Minerals 2020, 10, 868. [CrossRef]

76. Chen, Y.-M.; Gao, J.-B.; Yuan, Y.-Q.; Ma, J.; Yu, S. Relationship between heavy metal contents and clay mineral properties in surface sediments: Implications for metal pollution assessment. Cont. Shelf Res. 2016, 124, 125-133. [CrossRef]

77. Moreno, T.; Trechera, P.; Querol, X.; Lah, R.; Johnson, D.; Wrana, A.; Williamson, B. Trace element fractionation between PM10 and PM2.5 in coal mine dust: Implications for occupational respiratory health. Int. J. Coal Geol. 2019, 203, 52-59. [CrossRef]

78. Hryniv, S.M.; Peryt, T. Strontium distribution and celestite occurrence in Zechstein (Upper Permian) anhydrites Of West Poland. Geochemistry 2010, 70, 137-147. [CrossRef]

79. Du Preez, G.; Wepener, V.; Dennis, I. Metal enrichment and contamination in a karst cave associated with anthropogenic activities in the Witwatersrand Basin, South Africa. Environ. Earth Sci. 2016, 75, 1-13. [CrossRef]

80. Zgłobicki, W.; Telecka, M.; Skupiński, S. Heavy metals in playgrounds in Lublin (E Poland): Sources, pollution levels and health risk. Environ. Sci. Pollut. Res. 2020, 28, 18328-18341. [CrossRef] [PubMed]

81. Dytłow, S.; Górka-Kostrubiec, B. Concentration of heavy metals in street dust: An implication of using different geochemical background data in estimating the level of heavy metal pollution. Environ. Geochem. Health 2021, 43, 521-535. [CrossRef] [PubMed]

82. Querol, X.; Moreno, T.; Karanasiou, A.; Reche, C.; Alastuey, A.; Viana, M.; Font, O.; Gil, J.; De Miguel, E.; Capdevila, M. Variability of levels and composition of PM10 and PM2.5 in the Barcelona metro system. Atmos. Chem. Phys. 2012, 12, 5055-5076. [CrossRef]

83. Moreno, T.; Martins, V.; Querol, X.; Jones, T.; BéruBé, K.; Minguillón, M.C.; Amato, F.; Capdevila, M.; de Miguel, E.; Centelles, S.; et al. A new look at inhalable metalliferous airborne particles on rail subway platforms. Sci. Total Environ. 2015, 505, 367-375. [CrossRef]

84. Moreno, T.; Querol, X.; Martins, V.; Minguillón, M.C.; Reche, C.; Ku, L.H.; Eun, H.R.; Ahn, K.H.; Capdevila, M.; de Miguel, E. Formation and alteration of airborne particles in the subway environment. Environ. Sci. Process. Impacts 2017, 19, 59-64. [CrossRef]

85. Lee, Y.; Lee, Y.-C.; Kim, T.; Choi, J.S.; Park, D. Sources and Characteristics of Particulate Matter in Subway Tunnels in Seoul, Korea. Int. J. Environ. Res. Public Health 2018, 15, 2534. [CrossRef] [PubMed]

86. Isozaki, H.; Oosawa, J.; Kawano, Y.; Hirasawa, R.; Kubota, S.; Konishi, S. Measures against electrolytic rail corrosion in Tokyo Metro Subway Tunnels. Procedia Eng. 2016, 165, 583-592. [CrossRef]

87. Sawłowicz, Z.; Malinowski, Ł.; Giże, A.; Stanek, J.; Przybyło, J. Mineralogical-Geochemical Study of Corroded Iron-Based Metals from a Salt Mine Environment. Corrosion 2020, 76, 666-677. [CrossRef] 
88. Adamiec, E.; Jarosz-Krzemińska, E.; Wieszała, R. Heavy metals from non-exhaust vehicle emissions in urban and motorway road dusts. Environ. Monit. Assess. 2016, 188, 369. [CrossRef]

89. Minguillon, M.C.; Reche, C.; Martins, V.; Amato, F.; de Miguel, E.; Capdevila, M.; Centelles, S.; Querol, X.; Moreno, T. Aerosol sources in subway environments. Environ. Res. 2018, 167, 314-328. [CrossRef] [PubMed]

90. Martínez-Guijarro, R.; Paches, M.; Romero, I.; Aguado, D. Enrichment and contamination level of trace metals in the Mediterranean marine sediments of Spain. Sci. Total Environ. 2019, 693, 133566. [CrossRef]

91. Šebela, S.; Baker, G.; Luke, B. Cave Temperature and Management Implications in Lehman Caves, Great Basin National Park, USA. Geoheritage 2019, 11, 1163-1175. [CrossRef]

92. Badyda, A.J.; Grellier, J.; Dabrowiecki, P. Ambient PM2.5 Exposure and Mortality Due to Lung Cancer and Cardiopulmonary Diseases in Polish Cities. In Respiratory Treatment and Prevention. Advances in Experimental Medicine and Biology; Pokorski, M., Ed.; Springer: Cham, Switzerland, 2016; Volume 944. [CrossRef]

93. Wilczyńska-Michalik, W.; Wilczyński, M. Air pollution in Cracow-A glance into the future from a historical perspective. Geobalcanica 2017, 3, 79-82. [CrossRef]

94. Traczyk, P.; Gruszecka-Kosowska, A. The Condition of Air Pollution in Kraków, Poland, in 2005-2020, with Health Risk Assessment. Int. J. Environ. Res. Public Health 2020, 17, 6063. [CrossRef]

95. Kaczmarczyk, M.; Sowiżdżał, A.; Tomaszewska, B. Energetic and Environmental Aspects of Individual Heat Generation for Sustainable Development at a Local Scale-A Case Study from Poland. Energies 2020, 13, 454. [CrossRef]

96. Marszałek, M.; Alexandrowicz, Z.; Rzepa, G. Composition of weathering crusts on sandstones from natural outcrops and architectonic elements in an urban environment. Environ. Sci. Pollut. Res. 2014, 21, 14023-14036. [CrossRef] [PubMed]

97. Lopez-Arce, P.; Garcia-Guinea, J. Weathering traces in ancient bricks from historic buildings. Build. Environ. 2005, 40, 929-941. [CrossRef]

98. Yang, W.; Marshall, A.M.; Wanatowski, D.; Stace, L.R. An Experimental Evaluation of the Weathering Effects on Mine Shaft Lining Materials. Adv. Mater. Sci. Eng. 2017, 2017, 4219025. [CrossRef]

99. Marszałek, M.; Dudek, K.; Gaweł, A. Cement Render and Mortar and Their Damages Due to Salt Crystallization in the Holy Trinity Church, Dominicans Monastery in Cracow, Poland. Minerals 2020, 10, 641. [CrossRef]

100. Benavente, D.; de Jongh, M.; Cañaveras, J.C. Weathering Processes and Mechanisms Caused by Capillary Waters and Pigeon Droppings on Porous Limestones. Minerals 2021, 11, 18. [CrossRef]

101. Cultrone, G.; De la Torre, M.J.; Sebastian, E.M.; Cazalla, O.; Rodriguez-Navarro, C. Behavior of Brick Samples in Aggressive Environments. Water Air Soil Poll. 2000, 119, 191-207. [CrossRef]

102. Cultrone, G.; Arizzi, A.; Sebastián, E.; Rodríguez-Navarro, C. Sulfation of calcitic and dolomitic lime mortars in the presence of diesel particulate matter. Environ. Geol. 2008, 56, 741-752. [CrossRef]

103. Morillas, H.; Maguregui, M.; Gallego-Cartagena, E.; Marcaida, I.; Carral, N.; Madariaga, J.M. The influence of marine environment on the conservation state of Built Heritage: An overview study. Sci. Total Environ. 2020, 745, 140899. [CrossRef]

104. Vidal, F; Vicente, R.; Mendes Silva, J. Review of environmental and air pollution impacts on built heritage: 10 questions on corrosion and soiling effects for urban intervention. J. Cult. Herit. 2019, 37, 273-295. [CrossRef]

105. Alexandrowicz, Z.; Marszałek, M. Efflorescences on weathered sandstone tors in the Stone Town Nature Reserve in Ciężkowice the Outer Carpathians, Poland-their geochemical and geomorphological controls. Environ. Sci. Poll. Res. 2019, 26, 37254-37274. [CrossRef] [PubMed]

106. Lewandowska, A.; Falkowska, L. Sea salt in aerosols over the Southern Baltic. Part 2. The neutralizing properties of sea salt and ammonia. Oceanologia 2013, 55, 299-318. [CrossRef]

107. Adachi, K.; Buseck, P.R. Changes in shape and composition of sea-salt particles upon aging in an urban atmosphere. Atmos. Environ. 2015, 100,1-9. [CrossRef]

108. Perez, N.; Pey, J.; Reche, C.; Cortes, J.; Alastuey, A.; Querol, X. Impact of harbour emissions on ambient PM10 and PM2.5 in Barcelona (Spain): Evidences of secondary aerosol formation within the urban area. Sci. Total Environ. 2016, 571, 237-250. [CrossRef]

109. AzadiAghdam, M.; Braun, R.A.; Edwards, E.-L.; Bañaga, P.A.; Cruz, M.T.; Betito, G.; Cambaliza, M.O.; Dadashazar, H.; Lorenzo, G.R.; Ma, L.; et al. On the nature of sea salt aerosol at a coastal megacity: Insights from Manila, Philippines in Southeast Asia. Atmos. Environ. 2019, 216, 116922. [CrossRef]

110. Corral, A.F.; Dadashazar, H.; Stahl, C.; Edwards, E.-L.; Zuidema, P.; Sorooshian, A. Source Apportionment of Aerosol at a Coastal Site and Relationships with Precipitation Chemistry: A Case Study over the Southeast United States. Atmosphere 2020, $11,1212$. [CrossRef]

111. Wu, S.P.; Dai, L.H.; Zhu, H.; Zhang, N.; Yan, J.P.; Schwab, J.J.; Yuan, C.S. The impact of sea-salt aerosols on particulate inorganic nitrogen deposition in the western Taiwan Strait region, China. Atmos. Res. 2019, 228, 68-76. [CrossRef]

112. Chi, J.W.; Li, W.J.; Zhang, D.Z.; Zhang, J.C.; Lin, Y.T.; Shen, X.J.; Sun, J.Y.; Chen, J.M.; Zhang, X.Y.; Zhang, Y.M. Sea salt aerosols as a reactive surface for inorganic and organic acidic gases in the Arctic troposphere. Atmos. Chem. Phys. 2015, 15, 16715-16745. [CrossRef]

113. Wang, H.; Wang, X.; Yang, X.; Li, W.; Xue, L.; Wang, T.; Chen, J.; Wang, W. Mixed Chloride Aerosols and their Atmospheric Implications: A Review. Aerosol Air Qual. Res. 2017, 17, 878-887. [CrossRef] 
114. Jablońska, M.; Janeczek, J. Identification of industrial point sources of airborne dust particles in an urban environment by a combined mineralogical and meteorological analyses: A case study from the Upper Silesian conurbation, Poland. Atmos. Pollut. Res. 2019, 10, 980-988. [CrossRef]

115. Wilczyńska-Michalik, W.; Michalik, J.M.; Kapusta, C.; Michalik, M. Airborne Magnetic Technoparticles in Soils as a Record of Anthropocene. Atmosphere 2020, 11, 44. [CrossRef]

116. Jabłońska, M.; Rachwał, M.; Wawer, M.; Kądziołka-Gaweł, M.; Teper, E.; Krzykawski, T.; Smołka-Danielowska, D. Mineralogical and Chemical Specificity of Dusts Originating from Iron and Non-Ferrous Metallurgy in the Light of Their Magnetic Susceptibility. Minerals 2021, 11, 216. [CrossRef]

117. Wilczyńska-Michalik, W.; Dańko, J.; Michalik, M. Characteristics of particulate matter emitted from a coal-fired power plant. Pol. J. Environ. Sud. 2020, 29, 1411-1420. [CrossRef]

118. Falasco, E.; Ector, L.; Isaia, M.; Wetzel, C.E.; Hoffmann, L.; Bona, F. Diatom flora in subterranean ecosystems: A review. Int. J. Speleol. 2014, 43, 231-251. [CrossRef] 